\title{
Lipid-based Biomimetics in Drug and Vaccine Delivery
}

\author{
Ana Maria Carmona-Ribeiro \\ Biocolloids Lab, Instituto de Química, Universidade de São Paulo
}

Brazil

\section{Introduction}

Lipids provide adequate matrixes for supporting important biomolecules (proteins, DNA, oligonucleotides and polysaccharides) on model surfaces (latex, silica, silicon wafers, selfassembled monolayers, metals, polymers, insoluble drugs, biological cells and viruses). For example, biomolecular recognition between receptor and ligand can be isolated and reconstituted by means of receptor immobilization into supported lipidic bilayers on silica. This is an overview on novel lipid-based assemblies for drug and vaccine delivery. Especial emphasis will be on assemblies produced from the cationic, synthetic and unexpensive lipid dioctadecyldimethylammonium bromide (DODAB). DODAB vesicles interacted with negatively charged prokaryotic or eukaryotic cells with high affinity changing the cell surface charge from negative to positive and reducing cell viability. DODAB effects on cell viability (bacteria, fungus and cultured mammalian cells) revealed its high antimicrobial activity and differential cytotoxicity in vitro. DODAB bilayer fragments were combined with drugs, biomolecules or particles producing novel lipid-based biomimetics to deliver difficult drugs or design vaccines. Hydrophobic drug granules or aggregated recombinant antigens became well dispersed in water solution via lipid adsorption on drug particles as nanocapsules or protein adsorption onto supported DODAB bilayers. In other instances, hydrophobic drug molecules were attached as monomers to borders of lipid bilayer fragments yielding drug formulations effective in vivo at low drug-to-lipid-molar ratio. Cationic biomimetic particles from silica or latex covered with one cationic lipid bilayer proved effective for adsorption, presentation and targeting of biomolecules in vivo. Thereby antigens were effectively presented to the immune system by particles at defined and controllable sizes. The problem of delivering drugs, antigens or biomolecules to their targets in vivo is central and multidisciplinary and biomimetic assemblies are a major asset to improved and less toxic drug and vaccine delivery.

\section{The self-assembly of natural and synthetic lipids}

Liposomes were first produced in 1965 by Alec Bangham in Cambridge UK and looked like myelin figures forming coherent and closed concentric spheroidal bilayers. From these early days up to the present, the development and diversification of the liposome "membrane" 
model was astonishing (Bangham, 1983). Much of our present knowledge of membrane properties has been obtained with models prepared with phospholipids. From the late 1970's and early eighties, a variety of bilayer structures, formed by dialkyldimethylammonium halides (Kunitake et al., 1977) and other synthetic amphiphiles (Hargreaves \& Deamer, 1978; Mortara et al.,1978; Czarniecki \& Breslow, 1979; Suedholter et al., 1980) were introduced to mimic membrane properties and furnished unique opportunities to investigate structure-function relationships. Since the major requirement to form a supramolecular assembly of the bilayer type was an approximatelly cylindrical amphiphilic molecule with a geometric parameter between 0.5 and 1.0 (Israelachvili et al., 1977), not only natural phospholipids were prone to form bilayers. Structural and functional aspects of biological membranes were also copied in a variety of biomimetic systems. Bilayers were the preferential supramolecular assembly for several synthetic amphiphiles as dialkyldimethylammonium bromide or chloride (Kunitake et al., 1977), sodium dihexadecylphosphate (Mortara et al., 1978, Carmona-Ribeiro et al., 1991) and many other molecules (Furhhop \& Fristch, 1986; Segota \& Tezak, 2006). Figure 1 shows closed unilamellar vesicles and bilayer fragments of synthetic lipids.
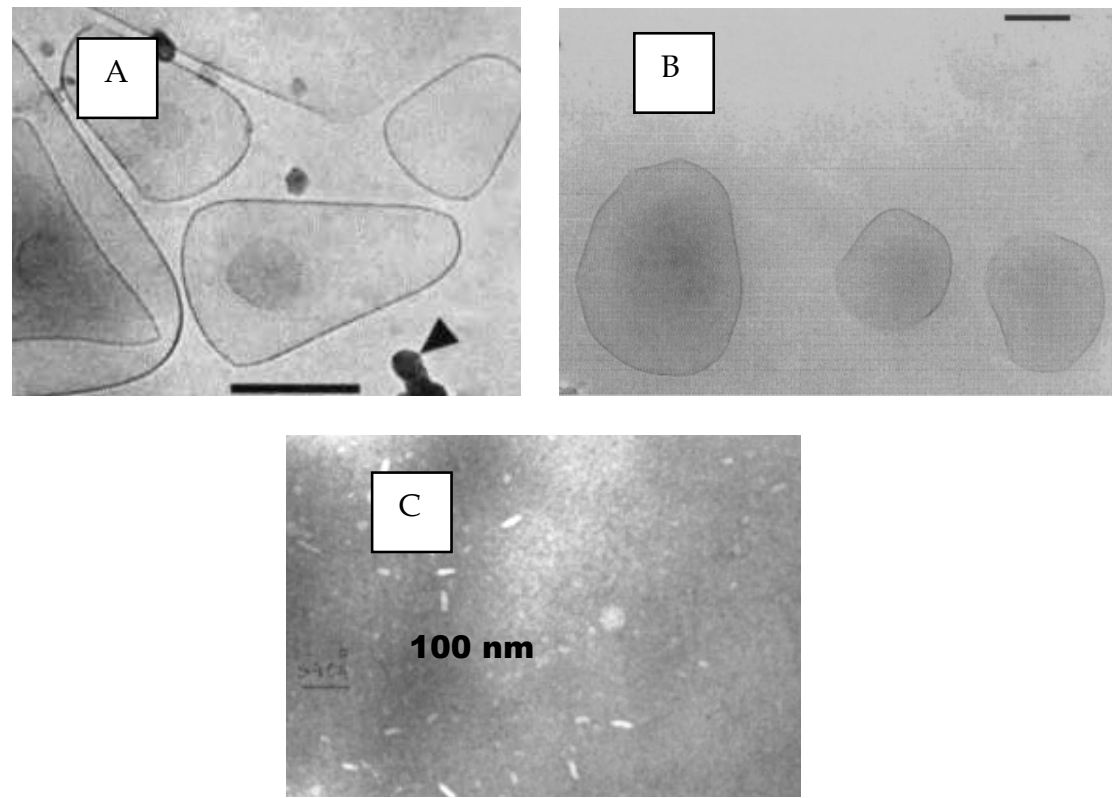

Fig. 1. Cryo-TEM images of DODAB vesicles obtained by vortexing (A) or extrusion (B) adapted with permission from Feitosa et al., 2006 and Lopes et al., 2008. Copyright 2006 and 2008 Elsevier. Ultrasonic vesicle disruption produced the bilayer fragments of DHP (C) adapted with permission from Carmona-Ribeiro et al., 1991. Copyright 1991 American Chemical Society. In (A, B ) bars correspond to $100 \mathrm{~nm}$ whereas in (C) $1 \mathrm{~cm}=100 \mathrm{~nm}$.

In the eighties, new possibilities for the synthesis of bilayer-forming compounds were just appearing. Novel amphiphiles were similar to natural phospholipid systems regarding bilayer structure and physical state, range of sizes, preparation methods available, water 
and solutes permeabilities and impermeability towards salts (Carmona-Ribeiro \& Chaimovich, 1983; Carmona-Ribeiro et al. 1984). Table 1 shows calculations of the geometric parameter for DODAB and DHP synthetic lipids.

\begin{tabular}{lllllll}
\hline Synthetic lipid & $\mathbf{C} / \mathbf{M}$ & $\mathbf{p H}$ & $\mathbf{v} / \mathbf{n m}^{3}$ & $\mathbf{l} / \mathbf{n m}$ & $\mathbf{a} / \mathbf{n m}^{2}$ & $\mathbf{v} / \mathbf{a l}$ \\
DODAB & 0 & 6.5 & 0.969 & 2.3 & 0.66 & 0.64 \\
& 0.0001 & & & & 0.54 & 0.79 \\
& 0.001 & & & & 0.52 & 0.81 \\
& 0.01 & & & & 0.52 & 0.81 \\
DHP & 0 & 7.8 & 0.862 & 2.1 & 0.425 & 0.99 \\
& 0.0001 & 7.3 & & & 0.427 & 0.985 \\
& 0.001 & 6.9 & & & 0.426 & 0.988 \\
& 0.01 & 6.2 & & & 0.421 & 1 \\
\hline
\end{tabular}

Table 1. Calculation of the geometric parameter v/al for DODAC and DHP assuming that the area per monomer a is equal to the limiting area per monomer at $25 \mathrm{mN} / \mathrm{m}$ in DODAC and DHP monolayers. $\mathrm{C}$ is the $\mathrm{NaCl}$ concentration. Adapted with permission from Claesson et al., 1989. Copyright 1989 American Chemical Society.

Vesicles exhibited basically 4 different operational types of stability: physical (mechanical), chemical, colloidal, and biological stability (Lasic, 1994). In the physical sense, vesicles were thermodynamically unstable because the symmetric membrane is curved and the excess energy of each vesicle due to its curvature is $8 \pi \mathrm{K}$, where $\mathrm{K}$ is the elastic bending module of the membrane. Vesicles could be formed spontaneously only in the case of bilayers with very low values of $\mathrm{K}$ (Talmon et al., 1983). A vesicle, however, was a much more stable physical entity than a micelle since the residence lifetime of one single molecule in the vesicle and in the micelle were ca. $10^{4}$ and $10^{-4} \mathrm{~s}$, respectively (Israelachvili et al., 1977). The much higher residence lifetime of one single molecule in the vesicle explained why micelles or microemulsions droplets quickly disintegrated upon dilution whereas vesicles and liposomes made from phospholipids or double-chained synthetic amphiphiles (with very low values of critical micelle concentration) remained stable against dilution. Mechanical properties of bilayers as measured by the micropipette manipulation technique indicated that mechanical properties such as stretching modulus can be correlated with liposome physical stability (Bloom et al., 1991). For example, a general observation was that cholesterol made more cohesive bilayers. Mechanical stabilization may also be achieved by polymerization (Hueb et al.,1980) or by using lipids with fluorocarbon chains (Kunitake, 1992). The chemical stability of liposomes was low because acid/base catalyzed hydrolysis might pinch off one or both hydrocarbon chains from the backbone of the lipid (Traueble \& Eibl, 1974) or oxidation might form cyclic peroxides at adjacent double bonds of the hydrocarbon chains resulting ultimately in the breakage of chains via lipoperoxidation (Chatterjee \& Agarwal, 1988). Hydrolysis rate of soybean lecithin in liposomes was $\mathrm{pH}$ and temperature dependent being at highest at extreme $\mathrm{pH}$ values where acid-base catalysis was enhanced and/or at the highest temperatures tested (Gritt \& Crommelin, 1992). Oxidation could be prevented by using saturated lipids and oxidation rates could be greatly reduced by adding antioxidants such as vitamin E or butylated hydroxytoluene (Lasic, 1994). 
Synthetic amphiphiles such as DODAB and DHP that form bilayers certainly are chemically more stable than natural lipids (Fuhrhop \& Fritsch, 1986). However, in contrast to natural lipids, which formed colloidally stable bilayer membranes at $150 \mathrm{mM}$ monovalent salt, $\mathrm{pH}$ 7.4, their colloid stability was low and their biological stability, ie their stability in the biological millieu, was poorly investigated (Carmona-Ribeiro \& Chaimovich, 1983; Carmona-Ribeiro et al. 1984). Furthermore, cytotoxicity for some synthetic amphiphiles as DODAB had been reported to be high, an apparent drawback that found useful applications in the design of liposomal antimicrobials where the liposomal carrier was not at all inocuous: vesicles and/or bilayer fragments playing an antimicrobial role by themselves (Tapias et al., 1994; Campanhã et al., 1999). Fig. 2 illustrated the efficacy of DODAB bilayer fragments against Escherichia coli.
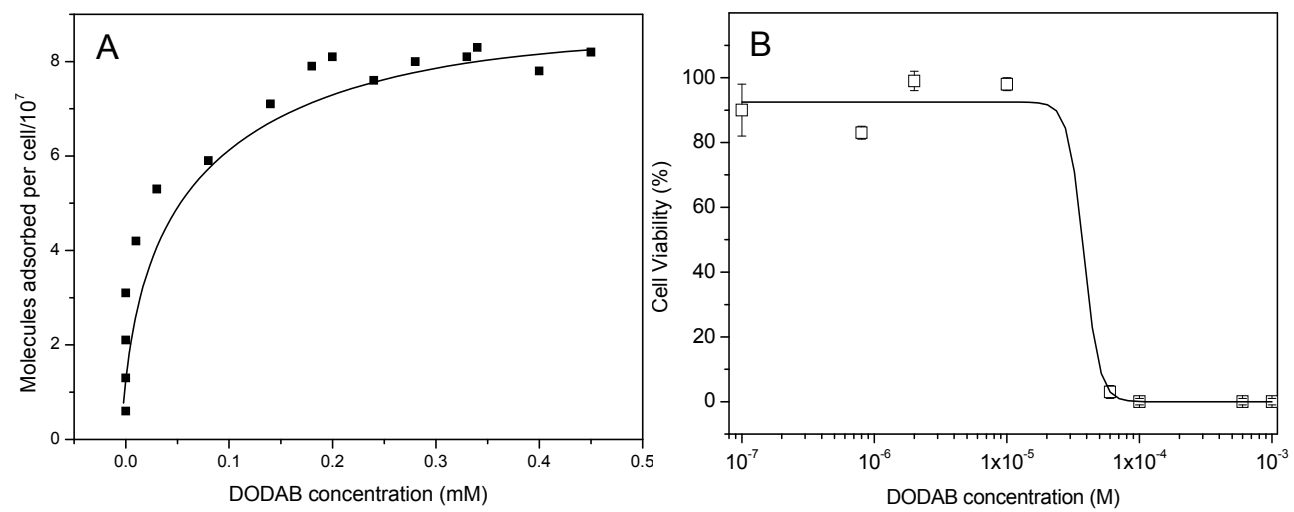

Fig. 2. Adsorption of DODAB BF onto Escherichia coli (A) profoundly affects E. coli viability (B). Adapted with permission from Campanhã et al., 1999, Tapias et al., 1994, Martins et al., 1997.Copyright 1994 and 1997 American Chemical Society.

In spite of its dose dependent-toxicity (Carmona-Ribeiro et al., 2006; Lincopan et al., 2006), DODAB capability to induce retarded hypersensibility, a marker for celullar immune responses, allowed DODAB to find important uses as an efficient immunoadjuvant mainly for veterinary uses but also in humans in a few instances (Gall, 1966; Dailey \& Hunter, 1974; Hilgers \& Snippe, 1992; Tsuruta et al., 1997; Klinguer-Harmour et al., 2002; Korsholm et al., 2007). Furthermore, we have been developing novel DODAB-based immunoadjuvants at reduced doses and toxicity.

\section{Surface functionalization by lipids}

Over the last two decades, lipid self-assembly at solid surfaces started to be better understood. In the eighties liposome adsorption was incidentally reported on clays, asbestos, Biobeads, gel filtration columns and membrane filters (Jackson et al., 1986). Lipid deposition from a lipidic vesicle onto a solid surface would be determined initially by the classical combination of a repulsive force arising from the interaction of the electrical double layers associated with the vesicle and the surface and the attractive dispersion force between the vesicle and the solid. Vesicles are not, however, permanent rigid structures, and 
depending on their size and chemical composition and that of the aqueous medium they can distort, aggregate, disrupt and fuse with each other. Deposition of vesicles onto a solid surface could give rise to any particular one or a combination of these processes. Unilamellar phosphatidylcholine vesicles were reported to break open and adhere to a mica surface to form a bilayer coating, in spite of the evidence for this being indirect as obtained from the measured separation between two surfaces when pushed together (Horn, 1984). Further compression of the closely apposed bilayers resulted in fusion into a single bilayer. Phospholipid monolayers with lipid haptens inserted were supported by hydrophobic glass and useful for specific adherence of macrophages and cell surface recognition studies, but did not serve as hosts for transmembrane proteins (Lin et al., 1982). Dipalmitoylphosphatidylcholine (DPPC) and phosphatidylinositol (PI) from vesicles adsorbed onto negatively charged ballotini (hydrophobic) glass beads as a monolayer with their head groups uppermost (Jackson et al., 1986). The easiest method for preparing high quality phospholipid bilayers on a flat hydrophilic surface was the direct fusion of small unilamellar vesicles, a method originated to make unilamellar membranes on glass coverslips for spectroscopic studies (Brian \& McConnell, 1984). Phospholipid fusion at the hydrophilic surface such as freshly cleaved mica could be induced at elevated temperatures for those lipids of higher transition temperature with traces of divalent cations such as $\mathrm{Ca}^{2+}$. The other method for preparing supported membranes of biological interest was the controlled transfer of monolayers to the surface using the Langmuir trough. Using this method the content in each leaflet was easily controlled, and the transfer pressure could be at a desirable value (Tamm \& McConnell, 1985). The main advantages of the vesicle fusion method seemed to be simplicity and the most natural lateral pressure in the bilayer in comparison to the lateral pressures obtained with the Langmuir trough. However, the content in each leaflet could not be controlled using fusion. A central problem in biology has been the structure of membranes and membrane proteins. Despite many years of intense effort, direct imaging of unsupported membranes such as the plasma membrane of an intact cell, did not appear very promising due to low resolution $(20 \mathrm{~nm})$. When such membranes, either artificially made or purified, were placed on a solid support, such as mica or glass cover slips, much higher resolution was demonstrated using the atomic force microscope AFM (Butt et al., 1990; Yang et al., 1993). This advance came with the AFM itself invented in 1986 (Binnig et al., 1986) and substantially improved in 1990, though AFM imaging of cells has not yielded sufficiently high resolution to identify membrane proteins (Shao \& Yang, 1995). In contrast, supported membranes on mica, obtained either via vesicle fusion or deposition from monolayers prepared in the Langmuir trough, were stable under the AFM for repeated scans and in various buffers; even the defects were found useful as a nice internal control that permited determination of bilayer thickness (Shao \& Yang, 1995). The optical detection AFM could easily operate in aqueous buffers transparent to the visible light and this capability was very important for biological applications that required full hydration for retention of the native structures. When a membrane of appropriate composition was made on a mica surface, peripheral membrane proteins could be easily added to the buffer to allow binding to the membrane. The most straightforward example was the case of the cholera toxin bound to supported bilayers that contained the cholera toxin receptor, the monosialoganglioside GM1. Shao and Yang found that the stability of the toxin on fluid phase bilayers, such as egg-PC could be as good as the one on gel phase bilayers, such as DPPC (Shao and Yang, 1995). The success of AFM imaging this toxin at 
intermediate ionic strength (up to $150 \mathrm{mM}$ ) opened the real possibility of imaging reconstituted membrane proteins under true physiological conditions. A second example was reconstitution of gramicidin A, a short trans-membrane peptide, incorporated in such supported bilayers resolved as a channel like depression of 1-2 nm (Mou et al., 1996). For integral membrane proteins, methods to incorporate the proteins into the supported planar membrane required vesicle fusion: either directly fusing vesicles that contained integral membrane proteins onto a supported substrate such a piece of quartz or glass coverslip or fusing them onto a substrate which was previously coated with a monolayer of lipids (Yang et al., 1993). The mechanism of such events was not understood. Palmitoyloleoylphosphatidylcholine (POPC) vesicles without major protuding molecular moieties spread on a glass surface and formed a supported planar bilayer whereas Escherichia coli lipid vesicles adsorbed as entire vesicles to the surface forming a supported vesicle layer on glass (Nollert et al., 1995). Escherichia coli lipids, a lipid mixture rich in lipopolysaccharides with bulky and strongly hydrated polarheads, did not form a supported bilayer on glass, vesicles simply adhered and formed a supported vesicle layer, lipopolysacharides accounting for the steric repulsion that prevented fusion inbetween vesicles attached to the surface (Nollert et al., 1995). For DPPC and DSPC bilayers on hydrophilic silicon/water interface, single and double bilayers have been prepared and characterized via neutron reflectivity to determine the structure, hydration and roughness of the layers; the distance between the two bilayers identified the second bilayer highly hydrated and floating at 2 to $3 \mathrm{~nm}$ above the first one (Charitat et al., 1999). Adhesion of a vesicle layer of dioctadecyldimethylammonium bromide (DODAB), a synthetic lipid with a poorly hydrated polar headgroup, onto the rough and highly hydrated surface of cells was electrostatically driven with cationic vesicles at low ionic strenght attracted to the negatively charged cell surface and surrounding the cell as a vesicle layer (Tapias et al., 1994). Absence of DODAB vesicle disruption upon interaction with the bacteria was depicted from absence of $\left[{ }^{14} \mathrm{C}\right]$-sucrose leakage from vesicles in experiments where this marker was used to label the inner water compartment of the vesicles (Martins et al., 1997). The differential cytotoxicity of DODAB lipid was illustrated in Table 2 (adapted from Carmona-Ribeiro, 2003; Carmona-Ribeiro, 2006; Mamizuka \& Carmona-Ribeiro, 2007).

\begin{tabular}{|c|c|c|c|}
\hline Cell type & $\begin{array}{l}\text { Viable } \\
\text { cells } / \mathrm{mL}\end{array}$ & $\begin{array}{l}\text { [DODAB] for } \\
50 \% \text { survival } \\
/ \mathrm{mM}\end{array}$ & Reference \\
\hline $\begin{array}{l}\text { Normal Balb-c 3T3 (clone } \\
\text { A31) mouse fibroblasts }\end{array}$ & $10^{4}$ & 1.000 & Carmona-Ribeiro et al., 1997 \\
\hline $\begin{array}{l}\text { SV40-transformed SVT2 } \\
\text { mouse fibroblasts }\end{array}$ & $10^{4}$ & 1.000 & Carmona-Ribeiro et al., 1997 \\
\hline C. albicans & $2 \times 10^{6}$ & 0.010 & Campanhã et al., 2001 \\
\hline E. coli & $2 \times 10^{7}$ & 0.028 & $\begin{array}{lll}\text { Martins et al., } & \text { 1997; } \\
\text { Campanhã et al., } 1999 & \end{array}$ \\
\hline S. typhimurium & $2 \times 10^{7}$ & 0.010 & Campanhã et al., 1999 \\
\hline P. aeruginosa & $3 \times 10^{7}$ & 0.005 & Campanhã et al., 1999 \\
\hline S. aureus & $3 \times 10^{7}$ & 0.006 & Campanhã et al., 1999 \\
\hline
\end{tabular}

Table 2. Differential cytotoxicity of DODAB cationic lipid. 
In conjunction with amphotericin B, DODAB bilayer fragments provided a novel drug formulation with excellent activity against systemic candidiasis in mice (Vieira \& CarmonaRibeiro, 2001; Lincopan et al. 2003) but low nephrotoxicity (Lincopan et al., 2005) (Figure 3).

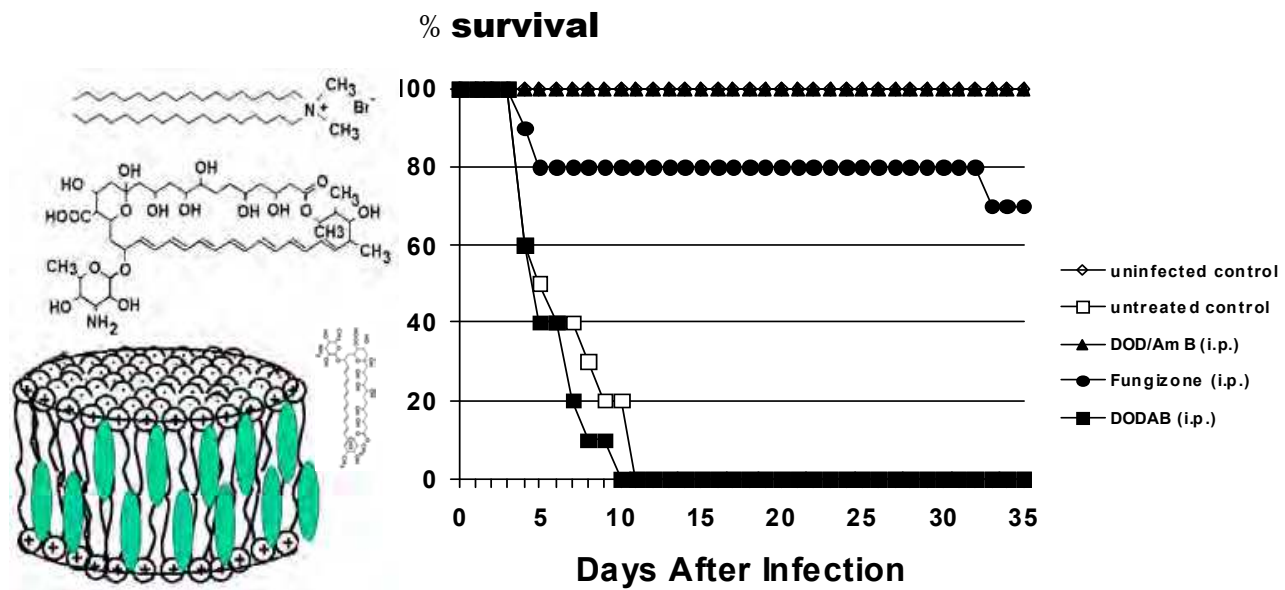

Fig. 3. Therapeutic activity of DODAB BF carrying monomeric amphotericin B in mice with candidiasis at low drug to lipid molar ratios. Adapted with permission from Vieira \& Carmona-Ribeiro, 2001. Copyright 2001 Elsevier; and from Lincopan et al., 2003. Copyright 2003 Oxford University Press.

\section{Particle functionalization by lipids}

A particle can be understood as a lipid particle (eg, a bilayer fragment), a polymeric particle, a mineral particle, a drug particle, a bacterium cell, a virus or a whole biological cell with several organelles. Even a supramolecular assembly of the coacervate type forming a microgel can be understood as a particle. Therefore, a broad variety of particulates can be functionalized by lipids depending on their interaction forces, intervening media and nature of the interacting pair. Bayerl and coworkers first demonstrated the formation of supported phospholipid bilayers on spherical silica beads (Bayerl \& Bloom, 1990), Esumi and coworkers deposited a DODAB layer (Esumi et al., 1992) and reported phospholipid adsorption on silica (Esumi \& Yamada, 1993) and Carmona-Ribeiro and coworkers first demonstrated deposition of a synthetic lipid bilayer onto oppositelly charged latex via electrostatic attraction (Carmona-Ribeiro \& Midmore, 1992) or deposition of a neutral phospholipid monolayer on amidine latex via hydrophobic interaction between hydrocarbon chains of the phospholipid and the hydrophobic latex surface (CarmonaRibeiro \& Herrington, 1993). Electrostatic attraction drove physical adsorption of charged bilayers onto oppositelly charged polymeric particles (Carmona-Ribeiro \& Midmore, 1992). Adsorption isotherms were of the Langmuir type and for the three different lipids studied the limiting areas at the polymer/water interface were consistent with bilayer deposition. Electrokinetic properties of the covered particles were very similar to those of vesicles; the mean-z-average diameter of particles in the latex/vesicle mixtures increased of $10 \mathrm{~nm}$, consistently with the increase in diameter expected from deposition of one bilayer on the 
particles (Carmona-Ribeiro \& Midmore, 1992). The interaction between lipids and particles has been reviewed over the last two decades in a few review articles and book chapters (Carmona-Ribeiro, 1992; Carmona-Ribeiro and Lessa, 1999; Carmona-Ribeiro, 2001 a,b; Carmona-Ribeiro, 2003; Carmona-Ribeiro et al., 2006; Carmona-Ribeiro, 2006; CarmonaRibeiro, 2007; Petri \& Carmona-Ribeiro, 2007; Mamizuka \& Carmona-Ribeiro, 2007) and lately other excellent reviews appeared in the literature (Bulte \& De Cuyper, 2003; Troutier \& Ladavière, 2007; Al-Jammal \& Kostarelos). Figure 4 illustrated possible assemblies resulting from the interaction between bilayer-forming lipids and particles as depicted from experimental evidences (Carmona-Ribeiro \& Midmore, 1992; Carmona-Ribeiro \& Herrington, 1993; Tsuruta et al., 1995; Rapuano \& Carmona-Ribeiro, 1997; Carmona-Ribeiro \& Lessa, 1999; Moura \& Carmona-Ribeiro, 2003; Moura \& Carmona-Ribeiro, 2005; Moura \& Carmona-Ribeiro, 2007).

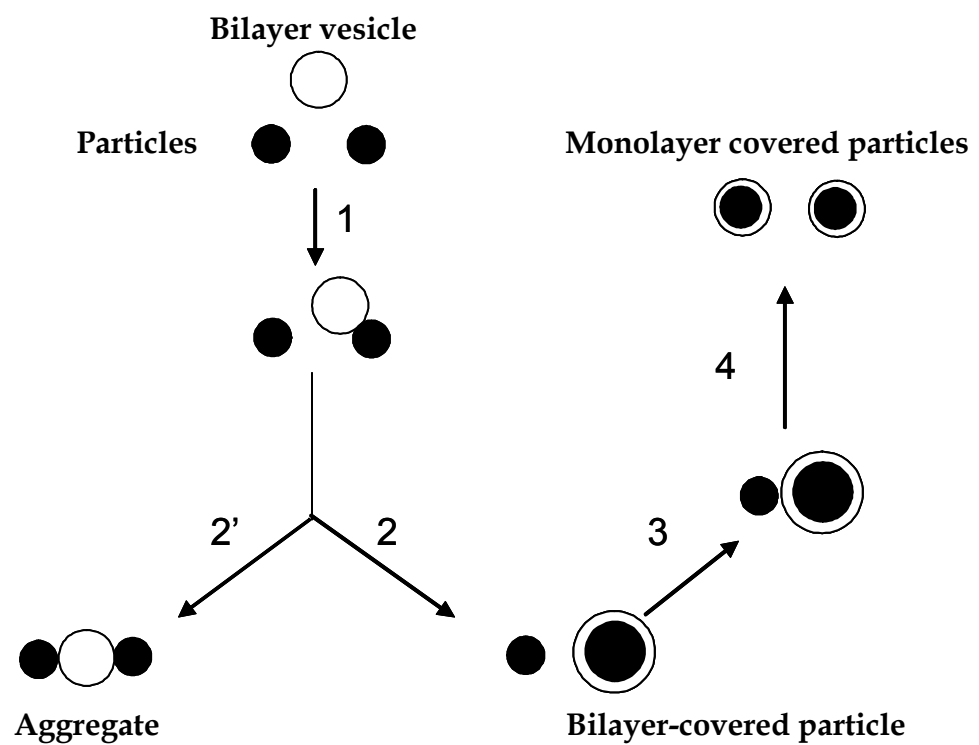

Fig. 4. The interaction between one bilayer vesicle and two particles. Adapted with permission from Carmona-Ribeiro \& Lessa, 1999. Copyright 1999 Elsevier.

For neutral phospholipids such as PC and DPPC, lipid adsorption was evaluated from adsorption isoterms and determination of mean-z-average diameter of particles in the latex/vesicle mixtures for three different latex dispersions: polystyrene with amidine, sulfate or carboxylate as functional groups (Carmona-Ribeiro \& Herrington, 1993). Small unilamellar phospholipid vesicles and polystyrene microspheres indeed interacted in aqueous solution to form homodisperse and stable phospholipid covered latexes. The amidine latex adsorbed neutral PC or DPPC vesicles revealing deposition of an odd number of monolayers: 1, 3, 5, etc (Carmona-Ribeiro \& Herrington, 1993). In a first step of the phospholipid vesicle /latex interaction, the vesicle would break open and the bilayer would adhere to the latex; in a second step the hydrophobic attraction between the phospholipid hydrocarbon chains in the bilayer and the hydrophobic polystyrene surface would disrupt the bilayer structure inducing coverage of the hydrophobic surface with one phospholipid 
monolayer with polar heads uppermost. Thereafter, upon increasing phospholipid concentration in the mixtures, the van der Waals attraction between the phospholipid layer on latex and free vesicles in the dispersion would drive deposition of a phospholipid bilayer onto the monolayer covered latex (Carmona-Ribeiro \& Herrington, 1993). The lipid coveredlatexes are useful as hosts for receptors (Sicchierolli \& Carmona-Ribeiro, 1995; Sicchierolli \& Carmona-Ribeiro, 1996; Moura \& Carmona-Ribeiro, 2006), reduced protein adsorption on the polymer (Sicchierolli \& Carmona-Ribeiro, 1996) and chromatography (Hautala et al., 2003; Haratake et al., 2007; Gulcev \& Lucy, 2008). Figure 5 showed cholera toxin immobilization onto cationic (A) or neutral biomimetic particles (B) schematically shown from Petri and Carmona-Ribeiro, 2007; Lincopan \& Carmona-Ribeiro, 2009; Moura \& Carmona-Ribeiro, 2005 and Moura \& Carmona-Ribeiro, 2006.
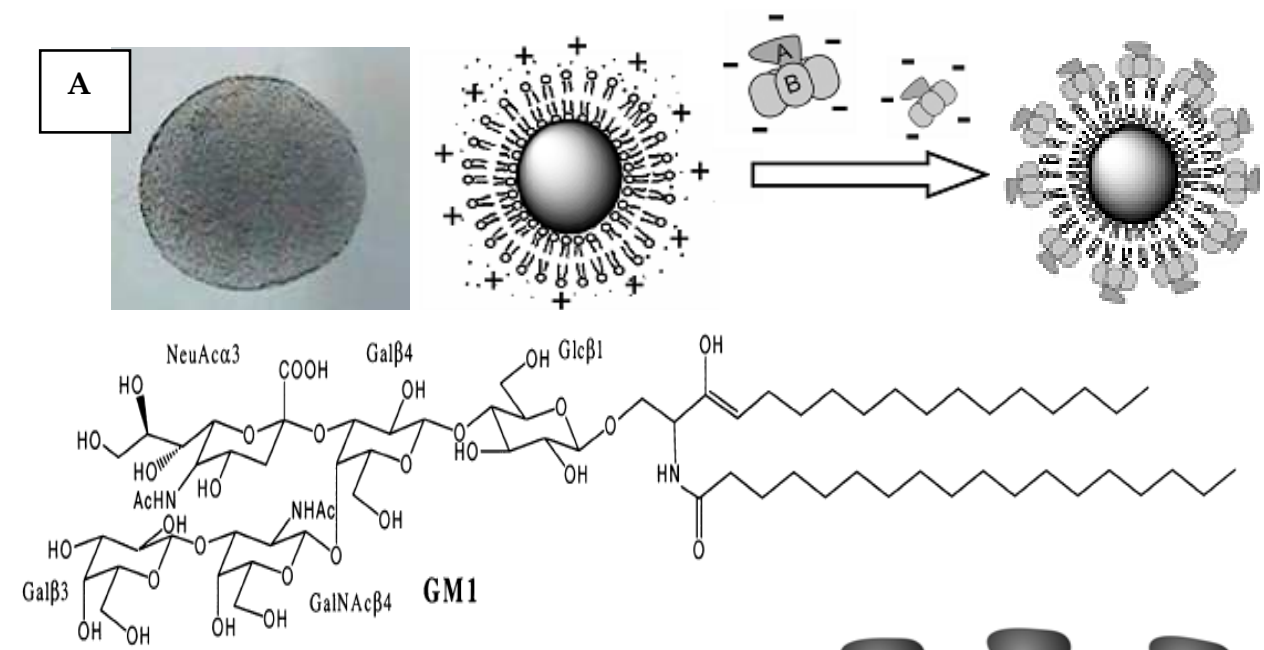

GM1
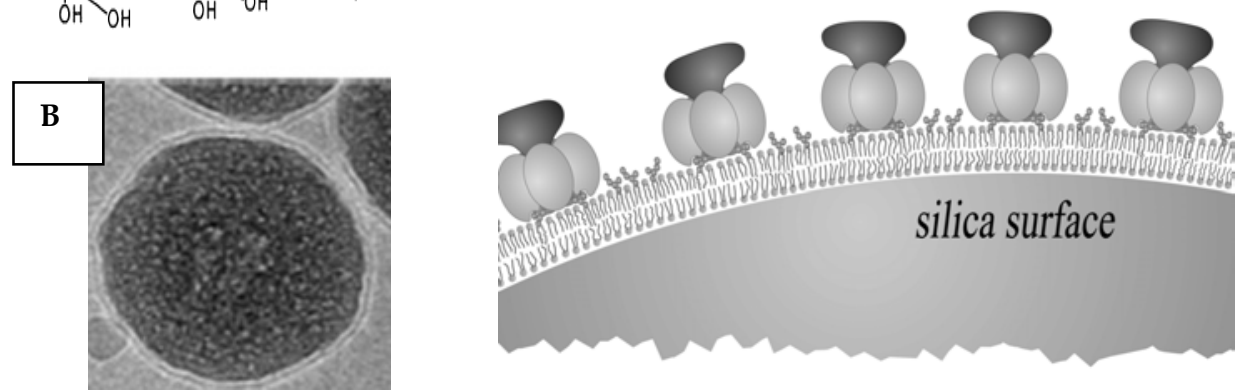

Fig. 5. Protein reconstitution onto biomimetic particles. Cholera toxin (CT) assembly onto polystyrene sulfate latex covered by a DODAB cationic bilayer (A) or CT specific binding to its GM1 receptor in phosphatidylcholine bilayers supported on silica particles (B). TEM (A) or cryo-TEM (B) revealed the cationic bilayer surrounding a polystyrene sulfate latex particle (A) or a PC bilayer surrounding a silica particle (B), respectively. Micrograph (B) was adapted with permission from Mornet et al., 2005. Copyright 2005 American Chemical Society. 
Although DODAC or DHP electrostatically adsorbed to oppositely charged polystyrene microspheres, forming homodisperse bilayer -covered latices, this took place only over a certain range of low lipid concentration. Beyond bilayer deposition, there was vesicle adhesion to the bilayer-covered latex (Tsuruta at al., 1995). For DODAC vesicles the extent of vesicle adhesion to the covered latex was much higher than for DODAB vesicles; no rupture of adhered vesicles being detected for DODAC but with rupture taking place for DODAB vesicles. Rupture for DODAB vesicles was associated with the absence of hydration repulsion inbetween adhered adjacent vesicles on the covered latex whereas absence of rupture for DODAC was related to occurrence of the short-ranged hydration repulsion (Tsuruta et al., 1995a). Using radiolabeled D-glucose inside the cationic vesicles at very low ionic strenght, cationic liposome adsorption was accompanied of vesicle disruption evidencing formation of a bilayer on the solid particle surface (Tsuruta et al., 1995a). A series of monodisperse sulfate polystyrene latex dispersions (76 -412 nm mean diameter) were covered with DODAB bilayers (Tsuruta et al., 1995b). The zeta-potential of these bilayercovered particles in water remained constant (and positive) over the entire range of sizes tested. The kinetics of $\mathrm{NaCl}$-induced flocculation for the bilayer-covered microspheres were obtained and the results used to construct curves of the logarithm of the stability ratio against the log of electrolyte concentration. At a given salt concentration, colloid stability increased, reached a maximum, and then decreased as a function of size. Slopes of the stability curves were calculated theoretically and compared with those obtained experimentally. The DLVO approximation by Reerink and Overbeek for an ideal colloid predicted an increase of slope with particle size which was not observed experimentally but DLVO models which include aggregation at the secondary minimum turned out to be qualitatively consistent with the experimental dependence of colloidal stability on particle size (Tsuruta et al., 1995b). DODA bromide (DODAB), chloride (DODAC), and acetate (DODAAc) bilayer-covered microspheres were more stable than vesicles of similar sizes under identical medium composition, vesicle colloidal instability due to asymmetry of charge distribution that occurs when salt is added to the vesicle outside, i. e. counterions bind at the outer vesicle surface but cannot bind at the inner vesicle surface because salt does not penetrate into the vesicle interior (Tsuruta \& Carmona-Ribeiro, 1996). With acetate as the counterion at $\mathrm{pH} 5.1-5.3$, specific acetate binding at the inner vesicle surface due to permeation of the neutral acetic acid through the vesicle membrane, thereby resulting in a high colloid stability. This stability was the highest ever observed for DODA vesicles. As counterion size and hydration increased (from bromide to acetate) so did colloid stability of vesicles and covered microspheres (Tsuruta \& Carmona-Ribeiro, 1996). The effect of increasing particle size was to decrease colloid stability due to reversible aggregation at a secondary minimum (Tsuruta \& Carmona-Ribeiro, 1996). Contact angle measurements on polystyrene or poly(styrene/ methacrylate) surfaces with aqueous DODAB, DODAC or DODAAc dispersions over a range of lipid concentrations $\left(10^{-6}-10^{-4} \mathrm{M}\right)$ were reported (Lessa \& Carmona-Ribeiro, 1996). For the polystyrene surface without charge, angles decreased as a function of lipid concentration for the three lipids, an indication that lipid molecules would be lying on the hydrophobic homopolymer whereas for the charged copolymers angles first increased and then attained a plateau value as a function of lipid concentration. Counterion effect on nature of the deposited lipid layer was to increase hydrophilicity according to: acetate>chloride>acetate whereas the effect of increasing the copolymer surface charge was to promote a higher degreee of vertical orientation of the 
hydrocarbon chains facilitating bilayer deposition (Lessa \& Carmona-Ribeiro, 1996). The most hydrophobic surface under air was the one obtained from the interaction between DODAB and the most charged copolymer. A DLVO model without free parameters did not account for the experimental colloid stability of a presumably ideal colloid such as latex covered with one DODAB bilayer (Carmona-Ribeiro \& Lessa, 1999). The experimental stability measured from $\mathrm{NaCl}$-induced flocculation was much smaller than the theoretical stability ratios suggesting either aggregation at a secondary minimum or an additional attractive force acting between the bilayer-covered particles not considered in the framework of the DLVO theory. Zeta-potential increased whereas experimentally measured colloid stability displayed a maximum as a function of particle size. Thus, over the range of larger particle sizes, upon increasing zeta-potential, there was a decrease in colloid stability. Possibly, calculations using adequate models that take into account this aggregation will shed new light on this issue. Whereas polystyrene microspheres have an hydrophobic surface, silica particles are good models for hydrophilic surfaces. Silica interacts with erythrocytes, lysosomes, macrophage plasma membranes and liposomes (Nash et al., 1966) but the mechanism of the interaction between silica and phospholipid membranes is still controversial. The main possibilities are: 1) silica particles binding DPPC through hydrogen bonds between $\mathrm{Si}-\mathrm{OH}$ and $\mathrm{O}=\mathrm{P}$ - groups; 2) tetraalkylammonium groups at the extracellular region of the erythrocyte membrane forming ion pairs with dissociated silanol on the silica particle and generating hemolytic effects observed for silica. Adsorption isotherms of 4 different bilayers on hydrophilic silica over a range of experimental conditions helped to clarify this issue (Rapuano \& Carmona-Ribeiro, 1997). The separate use of synthetic charged membranes with phosphate or tetraalkylammonium groups as polarheads such as are $\mathrm{DODAB}$ and DHP bilayer vesicles, to obtain adsorption isotherms on silica established the relative importance of phosphate or tetraalhylammonium on the mechanism of phospholipid deposition onto hydrophilic silica particles. Formation of ion pairs between the quaternary ammonium in the choline moiety of the phospholipid and the deprotonated silanol drove vesicle adhesion to the particle but vesicle rupture and bilayer deposition was determined by the cooperative occurrence of several hydrogen bridges between silanol and the phosphate moiety on the phospholipid (Rapuano \& Carmona-Ribeiro, 1997). A low affinity between neutral phospholipids and the silica surface and a high affinity for the cationic amphiphile over a range of $\mathrm{pH}$ values was obtained (Rapuano \& Carmona-Ribeiro, 2000). Tris-hydroxymethylaminomethane (Tris) used as buffer increased affinity between PC and silica at $\mathrm{pH} \leq 7.4$ due to Tris adsorption on silica with an increase in the surface density of hydroxyls on the surface available to hydrogen bridging with phosphate phospholipid groups. Bilayer deposition, however, was unambiguosly confirmed by the three techniques only for the interaction DPPC vesicles/silica over $1 \mathrm{~h}$ at $65{ }^{\circ} \mathrm{C}$ and for the interaction DODAB vesicles/silica over the all range of experimental conditions tested (Rapuano \& Carmona-Ribeiro, 2000). A simple spectrophotometric method for identifying entire bilayer deposition onto solid particles was developed from incorporation of the optical probe merocyanine 540 onto the outer bilayer vesicle surface. Upon bilayer deposition on the particle, sandwiching the marker between bilayer and solid particle reduced light absorption, this reduction being quantitatively related to bilayer deposition. For the interaction between cationic DODAB/DPPC and anionic PI/DPPC vesicles with zinc citrate dispersions the majority of the adsorption was in the form of intact liposomes (Catuogno \& Jones, 2000). Also, for several types of liposomes interacting with hydrophilic 
solid surfaces containing ionizable groups such as citrate or silanol, the $\mathrm{pH}$ affected the extent of adsorption, adsorption increasing with decreasing $\mathrm{pH}$ for anionic liposomes and increasing with increasing $\mathrm{pH}$ for cationic liposomes. The fusion and spreading of phospholipid bilayers on negatively charged glass surfaces is dependent on $\mathrm{pH}$ and ionic strength with membrane fusion of negatively charged membranes being favoured by low $\mathrm{pH}$ and high ionic strength as driven by the van der Waals attraction and membrane fusion of positively charged membranes onto the surface taking place under all conditions tested (Cremer \& Boxer, 1999). Figure 6 illustrated optimized bilayer deposition for PC on silica.

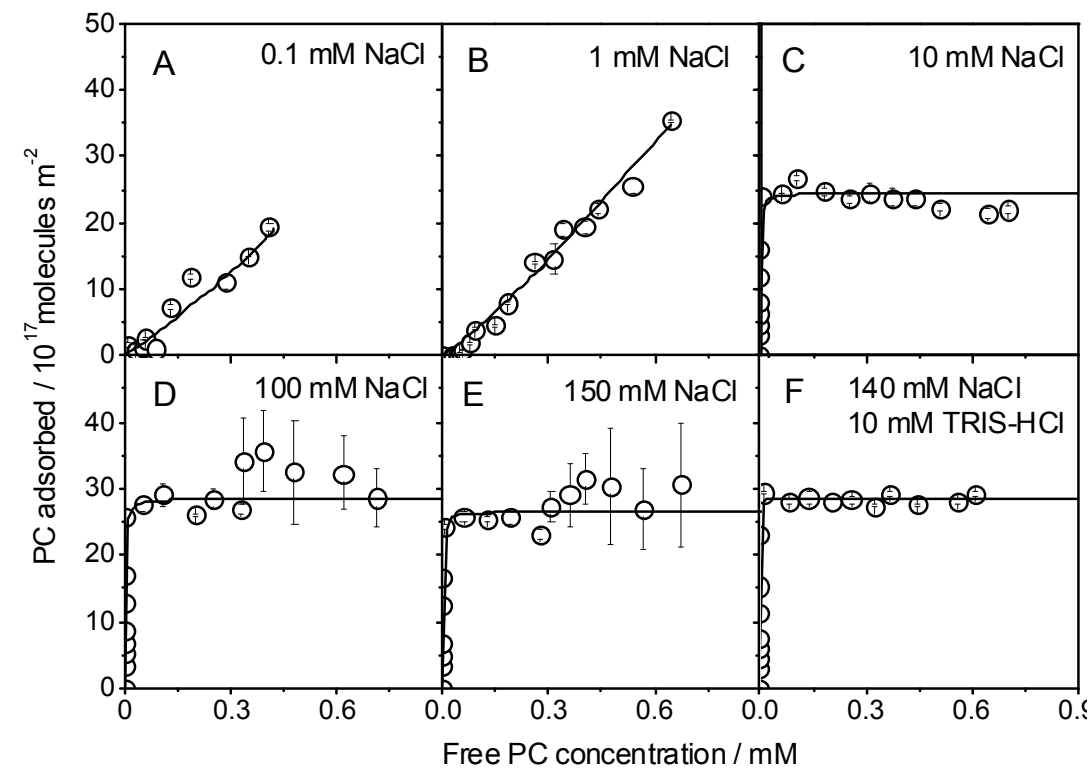

Fig. 6. Optimal bilayer coverage on silica from PC adsorption over a range of ionic strength. At maximal adsorption in C, D, E and F there is deposition of one PC bilayer onto particles. Reprinted with permission from Moura \& Carmona-Ribeiro, 2005. Copyright 2005 American Chemical Society.

Jones and coworkers prepared cationic and anionic liposomes from DPPC and in mixtures with cholesterol and DODAB and with phosphatidylinositol (PI) respectively covering a range of composition from 0 to 19 mole \% DODAB and PI producing supported vesicles on solid particles of silica and titanium dioxide (Bennet et al., 2000). Using encapsulation of radiolabeled D-glucose in the vesicles, they have shown that lipid adsorption on particles did not release the marker, an indication of adsorption of an intact vesicle layer onto the particles. Indeed, in the rigid gel state, bilayers are more difficult to disrupt as was the case for DODAB/DPPC vesicles adsorbing on silica (Moura \& Carmona-Ribeiro, 2007), with tightly packed bilayers (Sobral et al., 2008). There were important differences between the interactions that involve liposomes in the liquid-crystalline or in the gel state. Furthermore, differences in molecular geometry as predicted from the self-assembly model may lead to differences in packing of these molecules also at the solid surface. A cylindrical molecule 
prefers to deposit as a flat aggregate on a flat surface instead of depositing on highly curved particles. Molecular shapes departing from the cylindrical geometry such as the one of micelle -forming amphiphiles, adsorb onto hydrophobic surfaces as hemicylinders of liquidcrystalline aggregates (Manne \& Gaub, 1995). The bilayer bending for deposition on curved surfaces requires energy that can be offered by electrostatic attraction between oppositely charged groups on the bilayer or on the surface and/or highly cooperative hydrogen bonding between phospholipid polarheads and certain groups on the surface, e.g. silanols. From the comparison between langmuirian adsorption isotherms for PC, DPPC or DODAB deposition on silica particles (50 nm mean diameter), affinity constants for the surface increased in the following order PC $<$ DPPC $<$ DODAB (Rapuano and Carmona-Ribeiro, 1997; Rapuano and Carmona-Ribeiro, 2000). The molecular shape for PC in the bilayer is more cylindrical for PC than for DPPC, the geometric parameter for PC is larger than the geometric parameter for DPPC and it becomes difficult for the PC bilayer to bend and deposit on a curved silica particle but bending is easier for a DPPC bilayer. The contrary should be expected for PC and DPPC deposition on a silicon wafer as indeed observed (Salay \& Carmona-Ribeiro, 1999). Covering silica with a DODAB cationic bilayer in the rigid gel state was possible from the interaction between silica and bilayer fragments over a range of ratios between total surface areas for bilayer and silica particles $\left(A_{b} / A_{s}\right)$ and over a range of ionic strengths (Moura \& Carmona-Ribeiro, 2003). Thereby the difficulty of breaking open a vesicle that was in the rigid gel state was conveniently circumvented. Figure 7 illustrated colloid stability of silica/DODAB or silica/PC systems.

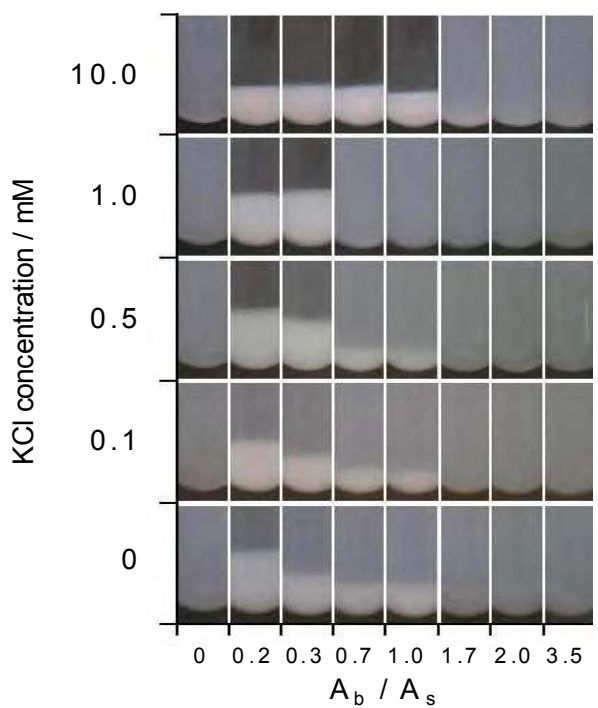

$[\mathrm{PC}]$
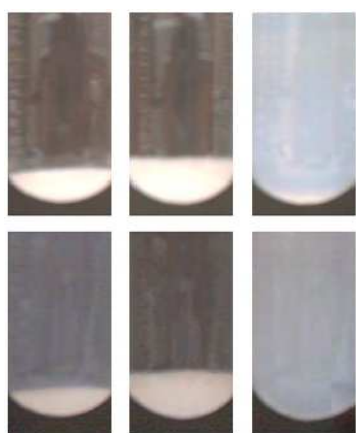

0.01

0.1

$0.7 \mathrm{mM}$

Fig. 7. Pictures of silica/DODAB (on the left) and silica/PC mixtures (on the right) at pH 6.3 on top or 7.4 on the bottom. Adapted with persmission from Moura \& Carmona-Ribeiro, 2003 and Moura \& Carmona-Ribeiro, 2005. Copyright 2003 and 2005 American Chemical Society. 
The use of membrane-coatings on colloidal particles offered an extensive repertoire of chemical functionality (Bayerl, 2004; Baksh et al., 2004). Glass microspheres coated with phospholipid layers evaluated the binding specificity of enzymes on cell surface (Obringer et al. 1995) or quantified lipid-antibodies binding (Kiser et al., 1998). Recent work continues to investigate lipid-supporting particles based on minerals (Lincopan et al. 2009; Nordlund et al. 2009; Ahmed \& Wunder, 2009; Xu et al., 2009; Oleson \& Sahai, 2008; Pyiasena et al., 2008; Senarath-Yapa et al. 2007; Moura \& Carmona-Ribeiro, 2007; Parida et al., 2006), polymers (Lincopan \& Carmona-Ribeiro, 2009; Jha \& Bose, 2009; Thevenot et al., 2008; Lincopan et al., 2007; Bershteyn et al. 2008; Zuzzi et al., 2008; Troutier et al., 2005; Pereira et al., 2004), metals eg magnetoliposomes for biomedical applications or contrast agents in magnetic resonance imaging (Bulte \& De Cuyper, 2003) or biological cells as templating cores to be dissolved to obtain capsules (Ge et al., 2003) or viruses for enhancing adenovirus tumor targeting in vivo (Singh et al., 2008). Polymer hollow capsules were produced by Möhwald and coworkers (Ge et al., 2003) from the polyelectrolyte layer-by-layer technique on biological cells. Permeability control of ions and small neutral molecules was achieved by analogy with the barrier function of biological membranes from the lipid coating on these capsules. Essentially, biomimetic particles composed of a particle core coated with lipids associated the advantages of particles and lipids. The solid core conferred mechanical stability to the lipid layers and, for biodegradable cores, particles could eventually be used in vivo as a carrier for bioactive compounds. The main advantages of the lipid envelop were biocompatibility, a biomimetic behavior of cell membranes and the ability to interact with a wide variety of molecules, either within the membrane or on the surface, depending on the physico-chemical properties of the carried species. The functionalization of colloidal particles with novel organoalkoxysilane-based lipids (Si-lipids) (Katagiri et al., 1999) pointed out the mechanic stability of a robust siloxane network at the particle-water interface (Katagiri \& Caruso, 2004).

\section{Lipid-based biomimetics for drug and vaccine delivery}

Liposomes and particles are both very versatile structures that are finding a large variety of biomedical and pharmaceutical applications. In general, particulate systems are naturally targeted to antigen presenting cells (APC) so that particles deliver antigens to APC more efficiently than soluble antigen (Kovacsovics-Bankowski et al., 1993; Vidard et al., 1996). For example, positively charged particles with diameters of $500 \mathrm{~nm}$ and below were shown to be optimal for dendritic cells uptake (Foged at al., 2005). Furthermore, it was recently shown that particles with positive charge showed higher internalization into human breast cancer cells than the nanoparticles with negative charge, while the degree of internalization of the positively- and negatively-charged nanoparticles into human umbilical vein endothelial cells was almost the same (Osaka et al., 2009). On the other hand, cationic lipids electrostatically combine with a vast variety of negatively charged biomolecules or biological structures besides being excellent antimicrobial agents by themselves (CarmonaRibeiro et al., 2006). Silica (Rapuano and Carmona-Ribeiro,1997, 2000; Moura and CarmonaRibeiro, 2005, 2006, 2007), latex (Carmona-Ribeiro and Midmore, 1992; Carmona-Ribeiro, 2001) or hydrophobic drug particles (Pacheco and Carmona-Ribeiro, 2003; Vieira et al., 2006; Lincopan and Carmona-Ribeiro, 2006) have been coated with cationic lipids. Optimal cationic bilayer deposition on particles was achieved by coalescence of bilayer fragments at 
adequate experimental conditions for the intervening medium such as $\mathrm{pH}$, ionic strength and concentrations of the interacting components (Moura \& Carmona-Ribeiro, 2003; Moura \& Carmona-Ribeiro, 2005; Pereira et al., 2004; Pereira et al., 2006). Recently, the optimal bilayer coverage of polystyrene sulfate (PSS) nanoparticles with a cationic dioctadecyldimethylammonium bromide (DODAB) bilayer found an important application adsorbing and successfully presenting antigens to the immune system (Lincopan et al., 2007; Lincopan et al., 2009a). From the literature, the potential of hybrid particle-lipid systems in diagnostics and therapeutics is starting to be realized (Carmona-Ribeiro, 2003; Katagiri et al., 2004; Pichot, 2004; Troutier et al. 2005; Urban and Lestage, 2006; Al-Jamal and Kostarelos, 2007; Petri and Carmona-Ribeiro, 2007; Singh et al., 2008; Soo et al., 2009). Bilayer-coated or solid lipid nanoparticles have also been employed to formulate other drugs. Recently, lipid nanoparticles of the anticancer drug chlorambucil were prepared by ultrasonication, using stearic acid as the core lipid and DODAB as surface modifier; it was observed that the presence of DODAB on the lipid nanoparticles resulted in greater accumulation of the drug in tumors (Sharma et al., 2009). For the encapsulation of cisplatin, bilayer-coating circumvented the limited solubility of cisplatin in water and produced cisplatin nanocapsules, bean-shaped nanoprecipitates of cisplatin coated by a lipid bilayer (Burger et al., 2002). The nanocapsules represented a novel lipid formulation of cisplatin characterized by a very high cisplatin-to-lipid ratio and cytotoxicity against tumor cells in vitro as compared to the free drug. The formation of the nanocapsules critically depended on the presence of negatively charged phospholipids and positively charged aqua-species of cisplatin (Burger et al., 2002; Chupin et al., 2004). The effect of PEG on the stability of the cisplatin nanocapsules was studied by incorporating PEG conjugated to phosphatidylethanolamine (DSPE-PEG2000) (Velinova et al., 2004). Cisplatin release from the nanocapsules depended on the temperature, the surrounding medium, and the lipid composition of the bilayer coat. Sterically stabilized cisplatin nanocapsules containing 6 mol\% DSPE-PEG served as the starting formulation for in vivo studies addressing the antitumor efficacy of cisplatin nanocapsules in tumor-bearing mice; there was a requirement of anionic phospholipid for successful nanoencapsulation of the cationic aqua-cisplatin (Velinova et al., 2004). DODAB or DHP bilayer fragments have been used to formulate hydrophobic drugs (Vieira \& Carmona-Ribeiro, 2001; Pacheco \& Carmona-Ribeiro, 2003; Lincopan et al., 2003; Carmona-Ribeiro, 2003; Vieira et al. 2006; Lincopan \& CarmonaRibeiro, 2006). Amphotericin B or miconazole were solubilized by bilayer fragments at low drug to lipid molar ratios (Vieira \& Carmona-Ribeiro, 2001; Pacheco \& Carmona-Ribeiro, 2003; Lincopan \& Carmona-Ribeiro, 2003) whereas at high drug to lipid molar ratios, drug particles were covered with synthetic bilayers from DODAB or DHP bilayer fragments (Pacheco \& Carmona-Ribeiro, 2003; Lincopan \& Carmona-Ribeiro, 2006). The combined action of lipid-covered miconazole and amphotericin B particles against Candida and C. neoformans was shown to depend on drug-to-lipid-molar proportion and interaction time (Lincopan and Carmona-Ribeiro, 2006). BF loading capacity for monomeric amphotericin B was $0.1 \mathrm{mM}$ amphotericin $\mathrm{B}$ at $2 \mathrm{mM}$ DODAB. Above this low drug-to-lipid molar proportion, all solubilization sites at the rim of the bilayer fragments were saturated and amphotericin B aggregated in the dispersion. At high drug-to-lipid molar proportions, addition of chaotropic $\mathrm{K}_{2} \mathrm{HPO}_{4}(0.2-2 \mathrm{mM})$ converted miconazole or amphotericin $\mathrm{B}$ aggregates into negatively charged particles with affinity for cationic lipid, which then surrounded each drug particle with a cationic layer. DODAB by itself killed C. neoformans 
and Candida at 2 and 2 to $>250 \mathrm{mg} / \mathrm{L}$ minimal fungicidal concentration (MFC). In combination, over the first hour, fungicidal activity was due to DODAB with lipid capsules retarding drug action. At $48 \mathrm{~h}$ and $10^{4} \mathrm{cfu} / \mathrm{mL}, \mathrm{MFC}(\mathrm{mg} / \mathrm{L})$ against Candida albicans was reduced from 4 to 1 amphotericin $\mathrm{B}$ (at $2 \mathrm{DODAB}$ ), and from 8 to 1 miconazole (at 1 DODAB). DODAB may be a suitable candidate for use in combination with miconazole for antifungal therapy due to reconfirmed synergistic action of both antimicrobial drugs: the cationic DODAB lipid and the microbicidal drug (Vieira et al., 2006; Lincopan and CarmonaRibeiro, 2006). Poly(ethylene glycol) (PEG) decorated lipid bilayers are widely used in drug delivery (Lasic, 1994). In these hybrid polymer/lipid systems, there is a transition from a dispersed lamellar phase (liposomes) to a micellar phase mediated by the formation of small discoidal micelles. The onset of disk formation took place at low PEG-lipid concentrations $(<5 \mathrm{~mol} \%)$ and the size of the disks decreased as more PEG-lipid was added to the lipid mixture (Johnsson \& Edwards, 2003). Stable dispersions dominated by flat bilayer disks could be prepared from a carefully optimized mixture of 1,2-distearoyl-sn-glycero-3phosphocholine (DSPC), cholesterol, and 1,2-distearoyl-sn-glycero-3-phosphoethanolamine$\mathrm{N}$-[methoxy(polyethyleneglycol)-5000][PEG-DSPE(5000)]. By varying the content of PEG DSPE (5000), the disks diameter varied from about 15 to $60 \mathrm{~nm}$. Disks compared favourably to uni- and multilamellar liposomes for hydrophilic drug partitioning employing immobilized disks in glass capillaries (Johansson et al., 2005). The major repulsive interactions preventing fusion of bilayer fragments and discs in dispersion are electrostatic, steric and/or eletrosteric (Carmona-Ribeiro, 2006). In particular, probe sonication of the synthetic and cationic lipid dioctadecyldimethylammonium bromide (DODAB) can yield disrupted vesicles: the bilayer fragments, BF, or disks (Carmona-Ribeiro, 2006). Bilayer disks are an attractive and sometimes superior alternative to liposomes (Nath et al., 2007; Johansson et al., 2007). Table 3 illustrated the efficacy of miconazole (MCZ) in DODAB or DHP bilayer fragments.

\begin{tabular}{lll}
\hline Drug or drug/lipid dispersion & \multicolumn{2}{l}{$\mathrm{MFC}$} \\
\cline { 2 - 3 } & $\mu \mathrm{M}$ & $\mathrm{mg} / \mathrm{mL}$ \\
Zoltec ${ }^{(F C Z)}$ & 6.5 & 2 \\
DODAB & 4000 & 250 \\
MCZ & 8 & 4 \\
MCZ and DODAB & 2 & 1 \\
MCZ and DHP & 4 & 2 \\
\hline
\end{tabular}

Table 3. Minimal fungicidal concentration (MFC) for miconazole (MCZ) in ethanol 4.3\%, $\mathrm{MCZ/DODAB}$ or DHP and Zoltec ${ }^{\circledR}$ (trade name for fluconazol) against Candida albicans ATCC 90028. Adapted with permission from Vieira et al 2006. Copyright 2006 Elsevier.

DODAB bilayer fragments (BF) were used for solubilization of hydrophobic drugs at low or high drug-to-lipid molar ratios (Vieira and Carmona-Ribeiro, 2001; Vieira and CarmonaRibeiro, 2008), as antimicrobial agent (Campanhã et al., 2000), or in the production of lipidcovered drug particles at high drug-to lipid molar ratios (Lincopan and Carmona-Ribeiro, 2006; Vieira and Carmona-Ribeiro, 2008) or bilayer-coated silica (Rapuano and CarmonaRibeiro, 2000; Moura and Carmona-Ribeiro, 2003) or latex (Carmona-Ribeiro and Midmore, 1992; Carmona-Ribeiro and Lessa, 1999). These cationic, bilayer-covered latex or silica particles where the bilayer is solely composed of DODAB were recently employed to 
present antigens to the immune system with better results than alum as adjuvants (Lincopan et al., 2007; Lincopan et al., 2009a,b,c). At low ionic strength, charged bilayer fragments (BF) were colloidally stable due to electrostatic repulsion. At low drug-to-lipid molar ratios, BF provided excellent solubilization sites for hydrophobic antifungal drugs so that drug granules of amphotericin B or miconazole could be completely solubilized at the rim of BF: monomolecular drug could be found well dispersed in water solution due to its selfassembly to the BF structure (Vieira and Carmona-Ribeiro, 2001; Pacheco and CarmonaRibeiro, 2003; Lincopan et al., 2003). At high drug-to-lipid molar ratios, minute amounts of bilayer fragments coalesced around each drug granule forming a lipidic capsule (Pacheco and Carmona-Ribeiro, 2003; Vieira et al., 2006; Lincopan and Carmona-Ribeiro, 2006). Therefore, these discoidal, charged bilayer fragments dispersed the hydrophobic drug particles in water both at low and at high drug-to-lipid molar ratios. Figure 8 showed effective formulations for amphotericin B at high drug to lipid molar ratio. Encapsulation of the drug particle by the cationic bilayer was followed by deposition of two more layers of polyelectrolytes (Pacheco \& Carmona-Ribeiro, 2003; Lincopan \& Carmona-Ribeiro, 2006; Vieira \& Carmona-Ribeiro, 2008).

STEP 1: Coverage of drug particle with cationic bilayer
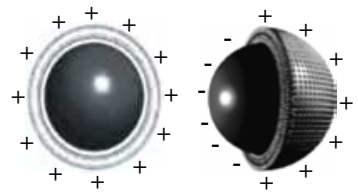

STEP 2: Coverage with anionic polymer layer

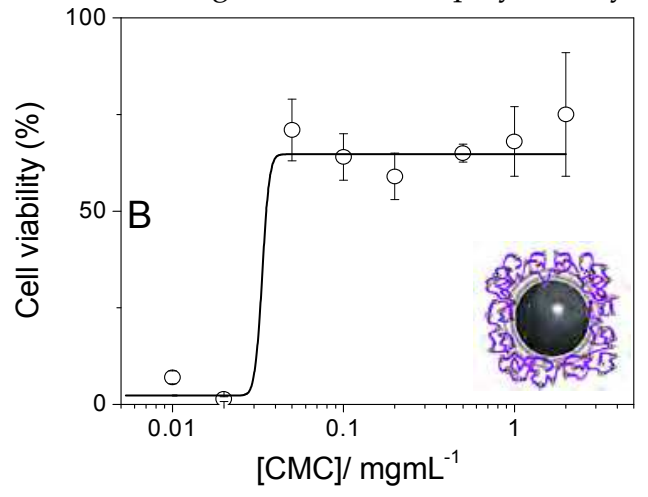

STEP 3: Coverage with cationic layer

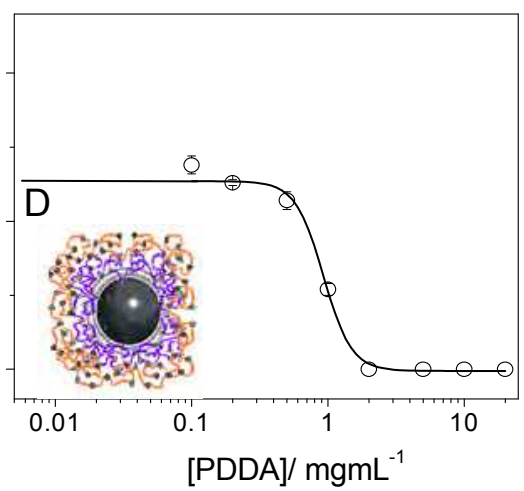

Fig. 8. Encapsulation of amphotericin B at high drug to lipid molar ratio. The insoluble drug particle is covered with a cationic bilayer, then covered by a layer of carboxymethylcellulose (CMC) and an outer layer of polydiallyldimethylamonium polymer (PDDA) becoming again positively charged and active against Candida albicans (Vieira \& Carmona-Ribeiro, 2008).

Electrostatically driven bilayer coverage from bilayer fragments onto oppositely charged latex produced a highly homodisperse particulate for biomolecules adsorption (CarmonaRibeiro and Midmore, 1992; Carmona-Ribeiro, 2001; Carmona-Ribeiro, 2003; Pereira et al., 2004; Lincopan et al., 2006; Lincopan et al., 2007; Rosa et al., 2008). Polystyrene sulfate (PSS) particles which are anionic can be covered with single cationic DODAB bilayers forming 
biomimetic particles prone to be used for DNA, proteins or antigen immobilization (Lincopan et al, 2006; Lincopan et al., 2007; Lincopan et al., 2009). Firstly, the DODAB/PSS assembly was characterized at $1 \mathrm{mM} \mathrm{NaCl}$ and $5 \times 10^{9}$ PSS particles/mL over a range of DODAB concentrations $(0.001-1 \mathrm{mM})$ by means of dynamic light scattering for particle sizing and zeta-potential analysis. $0.01 \mathrm{mM}$ DODAB was enough to produce perfectly homodisperse and cationic bilayer-covered particles. Secondly, under these experimental conditions, biomolecules or antigens adsorbed onto biomimetic particles with high affinity. Biomimetic particles were obtained in two-steps first covering the originally bare latex with a lipid layer and then, with a monomolecular biomolecule (protein or DNA) layer (Rosa et al., 2008; Lincopan \& Carmona-Ribeiro, 2009). PSS/DODAB/biomolecule assemblies were also characterized by means of dynamic light scattering and zeta-potential analysis yielding highly monodisperse particles at and above maximal adsorption. Cationic bilayer-covered particles were a highly organized and general support for biomolecules immobilization. The narrow size distribution and low polydispersity correlated well with superior cellular immune response towards the antigen (Lincopan et al., 2007) also observed for silica/DODAB particulates (Lincopan et al. 2009). Latex or polymeric particles can be useful as models for hydrophobic drug particles whereas silica or silicon wafers can mimic hydrophilic supports. Biomimetic particles as silica covered by one PC bilayer were obtained from quantification of PC adsorption onto silica (Moura and Carmona-Ribeiro, 2005). The effect of ionic strength and $\mathrm{pH}$ on phosphatidylcholine (PC) adsorption from vesicles on silica nanoparticles was investigated over a range of $[\mathrm{NaCl}](0.1-150 \mathrm{mM})$ at $\mathrm{pH}$ 6.3 and 7.4 by determing adsorption isotherms, colloid stability, particle size and zetapotentials. At and above $10 \mathrm{mM}$ ionic strength, $\mathrm{pH}$ 6.3, high-affinity adsorption with limiting adsorption at one-bilayer deposition on each silica particle was obtained. At $10 \mathrm{mM}$ ionic strength, adsorption isotherms indicated lower affinity between PC and silica at $\mathrm{pH} 7.4$ than at $\mathrm{pH}$ 6.3, reconfirming the important role of hydrogen bonding between silanoyl on silica and phosphate on PC in promoting bilayer deposition at $\mathrm{pH}$ of water. Under conditions where high affinity and bilayer deposition took place, silica sedimentation was absent, suggesting particle stabilization induced by bilayer coverage. At $150 \mathrm{mM} \mathrm{NaCl}$, the large colloid stability similarly achieved at $\mathrm{pH} 6.3$ or 7.4 suggested the major role of van der Waals attraction between the PC bilayer vesicle and the silica particle in determining bilayer deposition. Van der Waals attraction increased with ionic strength, causing PC vesicle disruption with bilayer deposition and silica stabilization. Major applications of supported bilayers on silica particles were isolation and reconstitution of receptor-ligand specific interaction (Moura and Carmona-Ribeiro, 2006) and antigens (proteins or DNA) presentation for vaccines (Rosa et al., 2008; Lincopan et al., 2009). Cholera toxin (CT) and its receptor, the monosialoganglioside GM1, a cell membrane glycolipid, self-assembled on PC bilayer-covered silica at 1 CT/5 GM1 molar ratio in perfect agreement with literature. Fig. 9 illustrated particles uptake by dendritic cells and the novel cationic imunoadjuvants.

\section{Conclusion}

Lipid association to polymeric, mineral, metal or drug particles has been optimized in order to achieve optimal bilayer deposition onto particles. Vesicle disruption, difficult for bilayers in the rigid gel state, was circumvented by employing previously disrupted charged vesicles: the bilayer fragments or disks. At appropriate intervening media, bilayer fragments 
coalesced around particles. Uses for biomimetic particles in drug and vaccine delivery were encapsulation of hydrophobic drugs, reconstitution of cell receptors, antigen presentation and antimicrobial therapy.
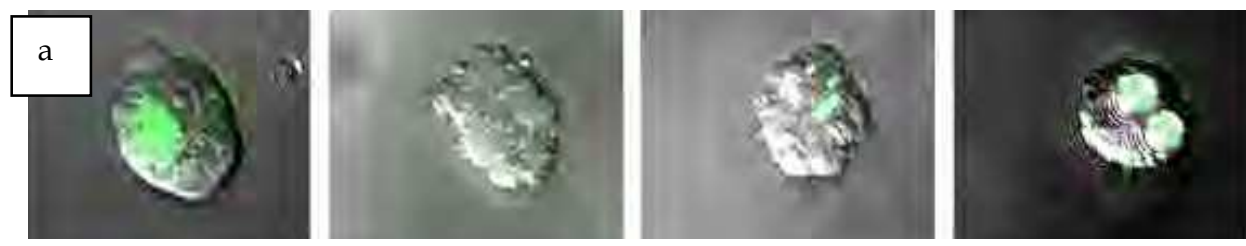

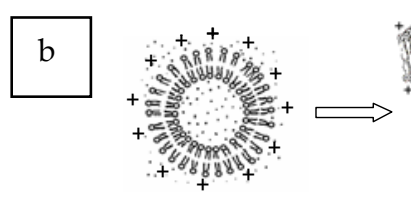

DODAB vesicle

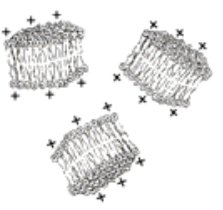

DODAB BF
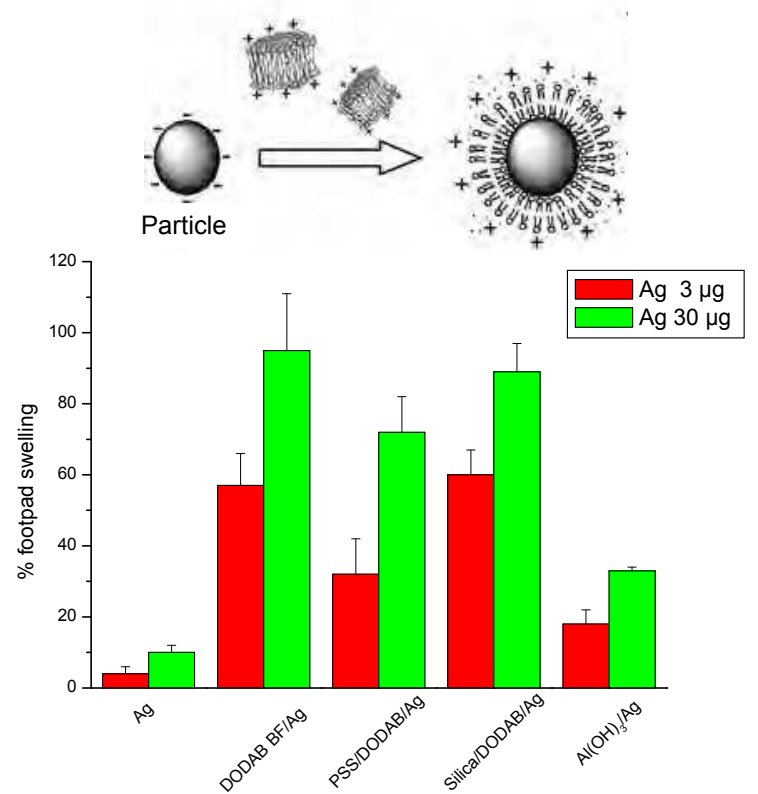
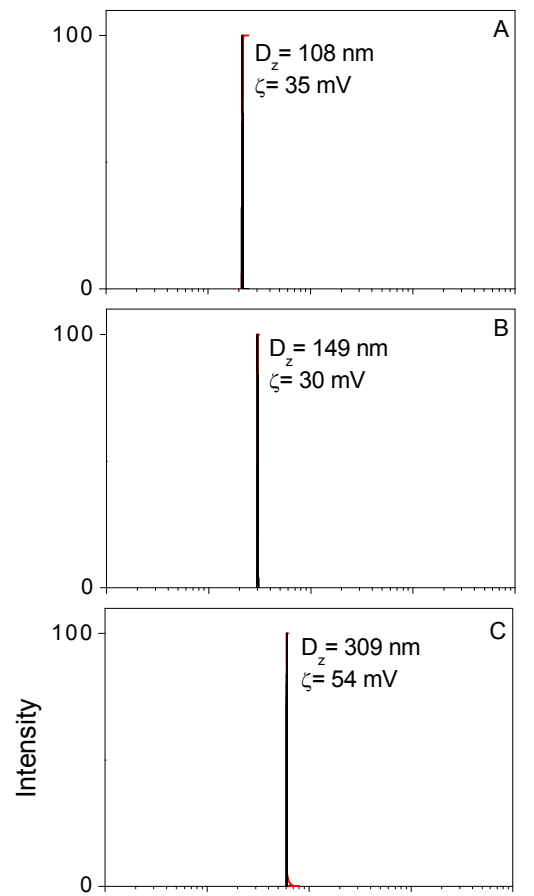

Fig. 9. (a) Uptake of carboxylated polystyrene particles (labeled in green) by dendritic cells from confocal overlaid with transmission pictures. From left to right microspheres were 0.1, 0.5, 1.0 and $4.5 \mu \mathrm{m}$ mean diameter. Adapted with permission from Foged et al, 2005, copyright 2005 Elsevier. (b) Cationic biomimetic particles (PSS/DODAB) with very narrow size distributions can be obtained over a range of sizes being effective as immuno adjuvants that elicit footpad swelling in mice and cellular immune response. Size distributions were reproduced with permission from Rosa et al., 2008. Copyright 2008 American Chemical Society. 


\section{Acknowledgments}

Financial support from FAPESP and CNPq is gratefully acknowledged.

\section{References}

Ahmed, S. \& Wunder, S. L. (2009). Effect of High Surface Curvature on the Main Phase Transition of Supported Phospholipid Bilayers on $\mathrm{SiO}_{2}$ Nanoparticles. Langmuir, 25, 6, (Mar 2009) 3682-91, ISSN 1053-0509.

Al-Jamal, W. T. \& Kostarelos, K. (2007). Liposome-nanoparticle hybrids for multimodal diagnostic and therapeutic applications. Nanomedicine, 2, 1, (Feb 2007) 85-98, ISSN 1743-5889.

Baksh, M. M.; Jaros, M. \& Groves, J. T. (2004). Detection of molecular interactions at membrane surfaces through colloid phase transitions. Nature, 427, 6970, (Jan 2004) 139-41, ISSN 0028-0836.

Bangham, A. D. (1983). Liposome Letters, Bangham, A. D., (Ed.), 1-405, Academic Press, ISBN 10: 0120777800, London.

Bayerl, T. M. (2004). A glass bead game. Nature, 427, 6970, (Jan 2004) 105-6, ISSN 0028-0836.

Bayerl, T. M. \& Bloom, M. (1990). Physical properties of single phospholipid bilayers adsorbed to micro glass beads. A new vesicular model system studied by ${ }^{2} \mathrm{H}-$ nuclear magnetic resonance. Biophys. J., 58, 2, 357-62, ISSN (electronic) 1542-0086.

Bennett, T. C. ; Creeth, J. E. \& Jones, M. N. (2000). Solid supported vesicles for bactericide delivery. J. Liposome Res., 10, 4, 303-20, ISSN: 0898-2104.

Bershteyn, A.; Chaparro, J.; Yau, R.; Kim, M. ; Reinherz, E. ; Ferreira-Moita, L. \& Irvine, D. J. (2008). Polymer-supported lipid shells, onions, and flowers. Soft Matter, 4, 9, (Apr 2008) 1787-91, ISSN 1744-683X.

Binnig, G. ; Quate, C. F. \& Gerber, C. H. (1986). Atomic Force Microscope. Phys Rev Lett., 56, 9, (Mar 1986) 930-33, ISSN 0031-9007.

Bloom, M.; Mouritsen, O. \& Evans, E. (1991). Physical properties of the fluid lipid-bilayer component of cell membranes: a perspective. Q. Rev. Biophys., 24, 3, (Aug 1991) 293397, ISSN 0033-5835.

Brian, A. A. \& McConnell, H. M. (1984). Allogeneic stimulation of cytotoxic T cells by supported planar membranes. Proc Natl Acad Sci U S A, 81, 19, (Oct 1984) 6159-63, ISSN 0027-8424.

Bulte, J. W. \& De Cuyper, M. (2003). Magnetoliposomes as contrast agents. Method. Enzymol., 373, 175-98, ISSN 0076-6879.

Burger, K. N. ; Staffhorst, R. W. ; de Vijlder, H. C. ; Velinova, M. J. ; Bomans, P. H. ; Frederik, P. M. \& de Kruijff, B. (2002). Nanocapsules: lipid-coated aggregates of cisplatin with high cytotoxicity. Nat. Med., 8, 1, (Jan 2002) 81-4, ISSN 1078-8956.

Butt, H. J.; Downing, K. H. \& Hansma, P. K. (1990). Imaging the membrane protein bacteriorhodopsin with the atomic force microscope. Biophys. J., 58, 6, (Dec 1990) 1473-80, ISSN (electronic) 1542-0086.

Campanhã, M. T. N.; Mamizuka, E. M. \& Carmona-Ribeiro, A. M. (1999). Interactions between cationic liposomes and bacteria: the physical-chemistry of the bactericidal action. J. Lipid Res., 40, 8, (1999 Aug) 1495-500, ISSN 0022-2275. 
Campanhã, M. T. N. ; Mamizuka, E. M. \& Carmona-Ribeiro, A. M. (2001). Interactions between cationic vesicles and Candida albicans. J. Phys. Chem. B, 105, 34, (Aug 2001), 8230-36, ISSN 1089-5647.

Carmona-Ribeiro, A. M. \& Chaimovich, H. (1983). Preparation and characterization of large dioctadecyldimethylammonium chloride liposomes and comparison with small sonicated vesicles. Biochim. Biophys. Acta, 733, 1, (Aug 1983) 172-9, ISSN 0006-3002.

Carmona-Ribeiro, A. M. ; Yoshida, L. S. ; Sesso, A. \& Chaimovich, H. (1984). Permeabilities and stabilities of large dihexadecylphosphate and dioctadecyldimethylammonium chloride vesicles. J. Colloid Interface Sci., 100, 2, (Aug 1984) 433-43, ISSN 0021-9797.

Carmona-Ribeiro, A. M. ; Castuma, C. E. ; Sesso, A. \& Schreier, S. (1991). Bilayer structure and stability in dihexadecyl phosphate dispersions. J. Phys. Chem., 95, 13, (June 1991) 5361-66, ISSN 0022-3654.

Carmona-Ribeiro, A. M. \& Midmore, B. R. (1992). Synthetic bilayer adsorption onto polystyrene microspheres. Langmuir, 8, 3, (Mar 1992) 801-6, ISSN 1053-0509.

Carmona-Ribeiro, A. M. (1992). Synthetic amphiphile vesicles. Chem. Soc. Rev., 21, 3, (1992) 209-14, ISSN 0306-0012.

Carmona-Ribeiro, A. M. \& Herrington, T. M. (1993). Phospholipid adsorption onto polystyrene microspheres. J. Colloid Interface Sci., 156, 1, (Mar 1993) 19-23, ISSN 0021-9797.

Carmona-Ribeiro, A. M. ; Ortis, F. ; Schumacher, R. I. \& Armelin, M. C. S. (1997). Interactions between cationic vesicles and cultured mammalian cells. Langmuir, 13, 8, (Apr 1997) 2215-18, ISSN 1053-0509.

Carmona-Ribeiro, A. M. \& Lessa, M. M. (1999). Interactions between bilayer vesicles and latex. Colloids Surf. A, 153, (1-3), (Aug 1999) 355-61, ISSN 0927-7757.

Carmona-Ribeiro, A. M. (2001). Bilayer vesicles and liposomes as interface agents. Chem. Soc. Rev., 30, 4, (Jun 2001), 241-47, ISSN 0306-0012.

Carmona-Ribeiro, A. M. (2001). Interactions between bilayer vesicles, biomolecules, and interfaces. In: Handbook of Surfaces and Interfaces of Materials, Nalwa, H. S., (Ed.), Vol. 5, 129-165, Academic Press, ISBN: 1588830690. San Diego.

Carmona-Ribeiro, A. M. (2003). Bilayer-forming synthetic lipids: drugs or carriers? Current Medicinal Chemistry, 10, 22, (Nov 2003) 2425-46, ISSN 0929-8673.

Carmona-Ribeiro, A. M.; Vieira, D. B. \& Lincopan, N. (2006). Cationic surfactants and lipids as anti-infective agents. Anti-Infective Agents in Medicinal Chemistry, 5, 1, (Jan 2006) 33-51, ISSN 1871-5214.

Carmona-Ribeiro, A. M. (2006). Lipid bilayer fragments and disks in drug delivery. Current Medicinal Chemistry, 13, 12, (May 2006) 1359-70, ISSN 0929-8673.

Carmona-Ribeiro, A. M. (2007). Biomimetic Particles in Drug and Vaccine Delivery. J. Liposome Res., 17, 3-4, (Dec 2007) 165-72, ISSN 0898-2104.

Catuogno, C. \& Jones, M. N. (2000). The interaction of cationic and anionic vesicles with zinc citrate dispersions. Colloids Surf. A, 163, (2000) 165-76, ISSN 0927-7757.

Charitat, T. ; Bellet-Amalric, E. ; Fragneto, G. \& Graner, F. (1999). Adsorbed and free lipid bilayers at the solid-liquid interface. Eur. Phys. J. B, 8, 4, (1999) 583-93, ISSN 14346028.

Chatterjee, S. N. \& Agarwal, S. (1988). Liposomes as membrane model for study of lipid peroxidation. Free Radicals Biology \& Medicine, 4, 1, (1988) 51-72, ISSN:0891-5849. 
Chupin, V.; de Kroon, A. I. P. M. \& de Kruijff, B. (2004). Molecular architecture of nanocapsules, bilayer-enclosed solid particles of cisplatin. J. Am. Chem. Soc., 126, 42, (Oct 2004) 13816-21, ISSN 0002-7863.

Claesson, P. M. ; Carmona-Ribeiro, A. M. \& Kurihara, K. (1989). Dihexadecyl phosphate monolayers: intralayer and interlayer interactions. J. Phys. Chem., 93, 2, (Jan 1989) 917-22, ISSN 0022-3654.

Cremer, P. S. \& Boxer, S. G. (1999). Formation and Spreading of Lipid Bilayers on Planar Glass Supports. J. Phys. Chem., 103, 13, (Mar 1999) 2554-59, ISSN 0022-3654.

Czarniecki, M. F. \& Breslow, R. (1979). Photochemical probes for model membrane structures. J. Am. Chem. Soc., 101, 13, (Jun 1979) 3675-6, ISSN 0002-7863.

Dailey, M. O. \& Hunter, R. L. (1974). The role of lipid in the induction of hapten-specific delayed hypersensitivity and contact sensitivity. J. Immunol., 112, 4, (Apr 1974) ISSN 1526-34.

Esumi, K. ; Sugimuro, T. ; Yamada, T. \& Meguro, K. (1993). Adsorption of dioctadecyldimethylammonium chloride on silica. Colloids \& Surfaces, 62, 5, (Feb 1992) 249-54, ISSN 0927-7757.

Esumi, K. \& Yamada, T. (1993). Characterization of a phospholipid adsorbed layer on silica from small unilamellar vesicles. Langmuir, 9, 2, (Feb. 1993) 622-4, ISSN 1053-0509.

Feitosa, E., Karlsson, G. \& Edwards, K. (2006). Unilamellar vesicles obtained by simply mixing dioctadecyldimethylammonium chloride and bromide with water. Chem. Phys. Lipids, 140, 1-2, (Apr 2006) 66-74, ISSN 0009-3084.

Foged, C., Brodin, B., Frokjaer, S. \& Sundblad, A. (2005). Particle size and surface charge affect particle uptake by human dendritic cells in an in vitro model. Int. J. Pharm., 298, 2, (Jul 2005) 315-22, ISSN 0378-5173.

Fuhrhop, J-H. \& Fritsch, D. (1986). Bolaamphiphiles form ultrathin, porous and unsymmetric monolayer lipid membranes. Acc. Chem. Res., 19, 5, (May 1986) 130-7, ISSN 0001-4842.

Gall, D., (1966). The adjuvant activity of aliphatic nitrogenous bases. Immunology 11, 4, (Oct 1966) 369-86, ISSN: 00192805.

Ge, L. ; Möhwald, H. \& Li, J. (2003). Polymer-stabilized phospholipid vesicles formed on polyelectrolyte multilayer capsules. Biochem. Biophys. Res. Commun., 303, 2, (Apr 2003) 653-9, ISSN: 0006-291X.

Gritt, M. \& Crommelin, D. J. A. (1992). The effect of aging on the physical stability of liposome dispersions. Chem. Phys. Lipids, 62, 2, (Sept 1992) 113-22, ISSN 0009-3084.

Gulcev, M. D. \& Lucy, C. A. (2008). Factors Affecting the Behavior and Effectiveness of Phospholipid Bilayer Coatings for Capillary Electrophoretic Separations of Basic Proteins. Anal. Chem., 80, 5, (Mar 2008) 1806-12, ISSN 0003-2700.

Haratake, M., Hidaka, S.; Ono, M. \& Nakayama, M. (2007). Preparation of an ionexchangeable polymer bead wrapped with bilayer membrane structures for high performance liquid chromatography. Anal. Chim. Acta, 589, 1, (Apr 2007) 76-83, ISSN 0003-2670.

Hargreaves, W. R. \& Deamer, D. W. (1978). Liposomes from ionic, single-chain amphiphiles. Biochemistry,17, 18, (Sep 1978) 3759-68, ISSN 0006-2960. 
Hautala, J. T. ; Linden, M. V. ; Wiedmer, S. K. ; Ryhanen, S. J. ; Saily, M. J. ; Kinnunen, P. K. J. \& Riekkola, M.-L. (2003). Simple coating of capillaries with anionic liposomes in capillary electrophoresis. Journal of Chromatography A, 1004, 1-2, (Jul 2003) 81-90, ISSN 0021-9673.

Hilgers, L. A. \& Snippe, H. (1992). DDA as an immunological adjuvant. Res. Immunol., 143, 5, (Jun 1992) 494-503, ISSN 0923-2494.

Horn, R. G. (1984). Direct measurement of the force between two lipid bilayers and observation of their fusion. Biochim. Biophys. Acta, 778, 1, (Nov 1984) 224-8, ISSN 0005-2736.

Hueb, H. H. ; Hupfer, B. ; Koch, H. \& Ringsdorf, H. (1980). Polymerizable phospholipid analogues--new stable biomembrane and cell models. Angew. Chem. Int. Ed. Engl., 1980, 19, (Dec 1980) 938-40, ISSN 1433-7851.

Israelachvili, J. N. ; Mitchell, D. J. \& Ninham, B. W. (1977). Theory of self-assembly of lipid bilayers and vesicles. Biochim. Biophys. Acta, 470, 2, (Oct 1977) 185-201, ISSN 00052736.

Jackson, S. ; Reboiras, M. D. ; Lyle, I. G. \& Jones, M. N. (1986). Adsorption of phospholipid vesicles on solid surfaces. Faraday Discuss. Chem. Soc., 81, 291-301, ISSN 0301-7249.

Jha, A. K. \& Bose, A. (2009). Surfactant Microstructure and Particle Aggregation Control Using Amphiphile Adsorption on Surface-Functionalized Polystyrene Spheres. Langmuir, 25, 1, (Jan 2009) 123-6, ISSN 1053-0509.

Johansson, E. ; Lundquist, A. ; Zuo, S. \& Edwards, K. (2007). Nanosized bilayer disks: attractive model membranes for drug partition studies. Biochim. Biophys. Acta 1768, 6, (Jun 2007) 1518-25, ISSN 0006-3002.

Johansson, E. ; Engvall, C. ; Arfvidsson, M. ; Lundahl, P. \& Edwards, K. (2005). Development and initial evaluation of PEG-stabilized bilayer disks as novel model membranes. Biophys. Chem., 113, 2, (Feb 2005) 183-92, ISSN 0301-4622.

Johnsson, M. \& Edwards, K. (2003). Liposomes, disks, and spherical micelles: aggregate structure in mixtures of gel phase phosphatidylcholines and poly(ethylene glycol)phospholipids. Biophys J., 85, 6, (Dec 2003) 3839-47, ISSN(electronic) 1542-0086.

Katagiri, K. \& Caruso, F. (2004). Functionalization of Colloids with Robust Inorganic-Based Lipid Coatings. Macromolecules, 37, 26, (Dec 2004) 9947-53, ISSN 0024-9297.

Katagiri, K. ; Ariga, J. \& Kikuchi, J. (1999). Preparation of Organic-Inorganic Hybrid Vesicle "Cerasome" Derived from Artificial Lipid with Alkoxysilyl Head. Chem. Lett., 28, 7, (Aug 1999) 661-2, ISSN 0366-7022.

Kiser, P. F. ; Wilson, G. \& Needham, D. (1998). A synthetic mimic of the secretory granule for drug delivery. Nature, 394, 6692, (Jul 1998) 459-62, ISSN 0028-0836.

Klinguer-Hamour, C. ; Libon, C. ; Plotnicky-Gilquin, H. ; Bussat, M. C. ; Revy, L. ; Nguyen, T. ; Bonnefoy, J. Y. ; Corvaia, N. \& Beck, A. (2002). Vaccine, 20, 21-22, (Jun 2002) 2743-51, ISSN 0264-410X.

Korsholm, K. S. ; Agger, E. M. ; Foged, C. ; Christensen, D. ; Dietrich, J. ; Andersen, C. S. ; Geisler, C.; Andersen, P. (2007). The adjuvant mechanism of cationic dimethyldioctadecylammonium liposomes. Immunology, 121, 2, (Jun 2007) 216-26, ISSN 00192805. 
Kovacsovics-Bankowski, M. ; Clark, K. ; Benacerraf, B. \& Rock, K. L. (1993). Efficient major histocompatibility complex class I presentation of exogenous antigen upon phagocytosis by macrophages. Proc. Natl. Acad. Sci. U.S.A., 90, 11, (Jun 1993) 4942-6, ISSN(electronic) 1091-6490.

Kunitake, T. (1992). Synthetic Bilayer Membranes: Molecular Design, Self-Organization, and Application. Angew. Chem. Int. Ed. Engl., 31, 6, (Jun 1992) 709-26, ISSN 1433-7851.

Kunitake, T. ; Okahata, Y. ; Tamaki, K. ; Kumamaru, F. \& Takayanagi, M. (1977). Formation of the bilayer membrane from a series of quaternary ammonium salts. Chem. Lett. 6 , 4, 387-90, ISSN 0366-7022.

Lasic, D. D. (1994). Sterically stabilized vesicles. Angew. Chem. Int. Ed. Engl., 33, 17, (Dec 1994) 1685-3, ISSN 1433-7851.

Lessa, M. M. \& Carmona-Ribeiro, A. M. (1996). Bilayer Wetting on Polymer Surfaces. J. Colloid Interface Sci., 182, 1, (Sep 1996) 166-71, ISSN 0021-9797.

Lin, L-C. ; Weis, R. M. \& McConnell, H. M. (1982). Induction of helical liposomes by $\mathrm{Ca}^{2+}$ mediated intermembrane binding. Nature, 296, 5853, (Mar 1982) 164-5, ISSN 00280836.

Lincopan, N. ; Mamizuka, E. M. \& Carmona-Ribeiro, A. M. (2003). In vivo activity of a novel amphotericin B formulation with synthetic cationic bilayer fragments. J Antimicrob Chemother.; 52, 3, (Sep 2003) 412-8, ISSN 0305-7453.

Lincopan, N. ; Mamizuka, E. M. \& Carmona-Ribeiro, A. M. (2005). Low nephrotoxicity of an effective amphotericin B formulation with cationic bilayer fragments. J Antimicrob Chemother., 55, 5, (Mar 2005) 727-34, ISSN 0305-7453.

Lincopan, N. \& Carmona-Ribeiro, A. M. (2006). Lipid-covered drug particles: combined action of dioctadecyldimethylammonium bromide and amphotericin B or miconazole. J Antimicrob Chemother., 58, 1, (Jul 2006) 66-75, ISSN 0305-7453.

Lincopan, N., Borelli, P., Fock, R., Mamizuka, E. M. \& Carmona-Ribeiro, A. M. (2006). Toxicity of an effective amphotericin B formulation at high cationic lipid to drug molar ratio. Exp Toxicol Pathol.,58, 2-3, (Nov 2006) 175-83, ISSN 0940-2993.

Lincopan, N. ; Rosa, H. \& Carmona-Ribeiro, A. M. (2006). Biomimetic Particles. Macromol. Symposia, 245-246, 1, (Feb 2007), 485-90, ISSN (electronic) 1521-3900.

Lincopan, N. ; Espíndola, N. M. ; Vaz, A. J. \& Carmona-Ribeiro, A. M. (2007). Cationic supported lipid bilayers for antigen presentation. Int. J. Pharm., 340, 1-2, (Aug 2007) 216-22, ISSN 0378-5173.

Lincopan, N. ; Santana, M. R. A. ; Faquim-Mauro, E. ; da Costa, M. H. B. \& Carmona-Ribeiro, A. M. (2009). Silica-based cationic bilayers as immunoadjuvants. BMC Biotechnol.,9, article 5, (Jan 2009) E-ISSN 1472-6750.

Lincopan, N. \& Carmona-Ribeiro, A. M. (2009). Protein assembly onto cationic supported bilayers. J. Nanosci. Nanotechnol., 9, 6, (Jun 2009) 3578-86, ISSN 1533-4880.

Lincopan, N. ; Espíndola, N. M. ; Vaz, A. J. ; da Costa, M. H. B.; Faquim-Mauro, E. \& Carmona-Ribeiro, A. M. (2009). Novel immunoadjuvants based on cationic lipid: preparation, characterization and activity in vivo. Vaccine, 27, 42, (Sep 2009) 5760-71, ISSN 0264-410X.

Lopes, A. ; Edwards, K. \& Feitosa, E. (2008). Extruded vesicles of dioctadecyldimethylammonium bromide and chloride investigated by light scattering and cryogenic transmission electron microscopy. J. Colloid Interface Sci., 322, 2, (Jun 2008) 582-8, ISSN 0021-9797. 
Mamizuka, E. M. \& Carmona-Ribeiro, A. M. (2007). Cationic Liposomes as Antimicrobial Agents, In: Communicating Current Research and Educational Topics and Trends in Applied Microbiology. Antonio Méndez Vilas, (Ed.), Vol. 2, 636-47. Formatex, ISBN: 978-84-611-94, Badajoz.

Manne, S. \& Gaub, H. (1995) Molecular Organization of Surfactants at Solid-Liquid Interfaces. Science, 270, 5241, (Dec 1995) 1480-2, ISSN 0036-8075.

Martins, L. M. S. ; Mamizuka, E. M. \& Carmona-Ribeiro, A. M. (1997). Cationic Vesicles as Bactericides. Langmuir, 13, 21, (Oct 1997) 5583-87, ISSN 1053-0509.

Messerschmidt, S. K. E., Musyanovych, A., Altvater, M., Scheurich, P., Pfizenmaier, K., Landfester, K., Kontermann, R. E. (2009). Targeted lipid-coated nanoparticles: Delivery of tumor necrosis factor-functionalized particles to tumor cells. J. Control. Release, 137, 1, (Jul 2009) 69-77, ISSN 0168-3659.

Mornet, S. ; Lambert, O. ; Duguet, E. \& Brisson, A. (2005). The Formation of Supported Lipid Bilayers on Silica Nanoparticles Revealed by Cryoelectron Microscopy. Nano Letters, 5, 2, (Feb 2005) 281-285.

Mortara, R. A. ; Quina, F. H. \& Chaimovich, H. (1978). Formation of closed vesicles from a simple phosphate diester. Preparation and some properties of vesicles of dihexadecyl phosphate. Biochem. Biophys. Res. Commun., 81, 4, (Apr 1978) 1080-6, ISSN 0006-291X.

Mou, J. ; Czajkowsky, D. M. ; Shao, Z. (1996). Gramicidin A aggregation in supported gel state phosphatidylcholine bilayers. Biochemistry, 35, 10, (Mar 1996) 3222-6, ISSN 0006-2960.

Moura S. P. \& Carmona-Ribeiro A. M. (2003). Cationic Bilayer Fragments on Silica at Low Ionic Strength: Competitive Adsorption and Colloid Stability. Langmuir, 19, 17, (Jul 2003) 6664-67, ISSN 1053-0509.

Moura, S. P. \& Carmona-Ribeiro, A. M. (2005). Biomimetic Particles: Optimization of Phospholipid Bilayer Coverage on Silica and Colloid Stabilization. Langmuir, 21, 22, (Jul 2005) 10160-4. ISSN 1053-0509.

Moura S. P., \& Carmona-Ribeiro A. M. (2007). Adsorption behavior of DODAB/DPPC vesicles on silica. J Colloid Interface Sci., 313, 2, (Sep 2007) 519-26, ISSN 0021-9797.

Moura, S. P. \& Carmona-Ribeiro, A. M. (2006). Biomimetic particles for isolation and reconstitution of receptor function. Cell Biochem Biophys. 44, 3, (Mar 2006) 446-52, ISSN1085-9195.

Nash, T. ; Allison, A. C. \& Harington, J. S. (1966). Physico-chemical properties of silica in relation to its toxicity. Nature, 210, 5033, (Apr 1966) 259-61, ISSN 0028-0836.

Nath, A.; Atkins, W. M. \& Sligar, S. G. (2007) Applications of Phospholipid Bilayer Nanodiscs in the Study of Membranes and Membrane Proteins. Biochemistry., 46, 8, (Feb 2007) 2059-69, ISSN 0006-2960.

Nollert, P. ; Kiefer, H. \& Jaehnig, F. (1995). Lipid vesicle adsorption versus formation of planar bilayers on solid surfaces. Biophys. J., 69, 4, (Oct 1995) 1447-55, ISSN (electronic) 1542-0086.

Nordlund, G. ; Lonneborg, R. \& Brzezinski, P. (2009). Formation of Supported Lipid Bilayers on Silica Particles Studied Using Flow Cytometry. Langmuir, 25, 8, (Apr 2009) 46016, ISSN 1053-0509. 
Obringer, A. N. ; Rote, N. S. \& Walter, A. (1995). Antiphospholipid antibody binding to bilayer-coated glass microspheres. J. Immunol. Methods., 185, 1, (Sep 1995) 81-93, ISSN 0022-1759.

Oleson, T. A. \& Sahai, N. (2008). Oxide-Dependent Adsorption of a Model Membrane Phospholipid, Dipalmitoylphosphatidylcholine: Bulk Adsorption Isotherms. Langmuir, 24, 9, (May 2008) 4865-73, ISSN 1053-0509.

Osaka, T., Nakanishi, T., Shanmugam, S., Takahama, S. \& Zhang, H. (2009). Effect of surface charge of magnetite nanoparticles on their internalization into breast cancer and umbilical vein endothelial cells. Colloids \& Surf. B: Biointerfaces, 71, 2, (Jul 2009) 32530, ISSN 0927-7765.

Pacheco, L. F. \& Carmona-Ribeiro, A. M. (2003). Effects of synthetic lipids on solubilization and colloid stability of hydrophobic drugs. J. Colloid Interface Sci., 258, 1, (Feb 2003) 146-54, ISSN 0021-9797.

Pacheco, L. F.; Vieira, D. B.; Correia, F. M. \&, Carmona-Ribeiro, A. M. (2004). Interactions between cationic bilayers and Candida albicans cells, In: Surface and Colloid Science, Galembeck, F., (Ed.), 175-77., Springer, ISBN 978-3-540-21247-8, Heidelberg.

Parida, S. K.; Dash, S. ; Patel, S. \& Mishra, B. K. (2006). Adsorption of organic molecules on silica surface. Adv. Colloid and Interface Sci., 121, 1-3, (2006)77-110. ISSN:0001-8686.

Pereira, E. M. A.; Vieira, D. B. \& Carmona-Ribeiro, A.M. (2004). Cationic bilayers on polymeric particles: effect of low $\mathrm{NaCl}$ concentration on surface coverage. J. Phys. Chem. B, 108 (31), (Jun 2004) 11490-5, ISSN 1089-5647.

Pereira, E. M. A. ; Petri, D. F. S. \& Carmona-Ribeiro, A. M. (2006). Adsorption of Cationic Lipid Bilayer onto Flat Silicon Wafers: Effect of Ion Nature and Concentration. J. Phys. Chem. B., 110, 20, (May 2006) 10070-74, ISSN 1089-5647.

Petri, D. F. S. \& Carmona-Ribeiro, A. M. (2007). Biomimetic particles, In: Polymeric Nanostructures and Their Applications. Nalwa, H. S. (Ed.), Vol. 1, 485-530, American Scientific Publishers, ISBN 1-58883-068-3, Valencia CA.

Pichot, C. (2004) Surface-functionalized latexes for biotechnological applications. Curr. Op. Coll. Interface Sci. 9, 3-4, (Nov 2004) 213-21, 1359-0294.

Piyasena, M. E. ; Zeineldin, R. ; Fenton, K. ; Buranda, T. \& Lopez, G. P. (2008). Biosensors based on release of compounds upon disruption of lipid bilayers supported on porous microspheres. Biointerphases, 3, 2, (Jun 2008) ISSN 1559-4106.

Rapuano, R. \& Carmona-Ribeiro, A. M. (1997). Physical adsorption of bilayer membranes on silica. J. Colloid Interface Sci., 193, 1, (Sep 1997) 104-11, ISSN 0021-9797.

Rapuano, R. \& Carmona-Ribeiro, A. M. (2000). Supported bilayers on silica. J. Colloid Interface Sci., 226, 2, (Jun 2000) 299-307, ISSN 0021-9797.

Rosa, H.; Petri, D. F. S. \& Carmona-Ribeiro, A. M. (2008). Interactions between bacteriophage DNA and cationic biomimetic particles. J. Phys. Chem. B., 112, 51, (Dec 2008) 16422-30, ISSN 1089-5647.

Salay, L. C. \& Carmona-Ribeiro, A. M. (1999). Wetting of $\mathrm{SiO}_{2}$ surfaces by phospholipid dispersions. J. Adhes. Sci. Technol., 13, 10, (1999) 1165-79, ISSN 0169-4243.

Segota, S. \& Tezak, D. (2006). Spontaneous formation of vesicles. Adv. Colloid Interface Sci, 121, 1-3, (Sep 2006) 51-75. ISSN 0001-8686. 
Senarath-Yapa, M. D. ; Phimphivong, S. ; Coym, J. W. ; Wirth, M. J. ; Aspinwall, C. A. \& Saavedra, S. S. (2007). Preparation and Characterization of Poly(lipid)-Coated, Fluorophore-Doped Silica Nanoparticles for Biolabeling and Cellular Imaging. Langmuir, 23, 25, (Dec 2007) 12624-33, ISSN 1053-0509.

Shao, Z. \& Yang, J. (1995). Progress in high resolution atomic force microscopy in biology. Q. Rev. Biophys., 28, 2, (May 1995) 195-251, ISSN 0033-5835.

Sharma, P. ; Ganta, S. ; Denny, W. A. \& Garg, S. (2009). Formulation and pharmacokinetics of lipid nanoparticles of a chemically sensitive nitrogen mustard derivative: Chlorambucil. Int. J. Pharm., 367, 1-2, (Feb 2009) 187-94, ISSN 0378-5173.

Sicchierolli, S. M. \& Carmona-Ribeiro, A. M. (1996). Biomolecular recognition at phospholipid-covered polystyrene microspheres. J. Phys. Chem., 100, 41, (Oct 1996) 16771-5, ISSN 0022-3654.

Sicchierolli, S. M. \& Carmona-Ribeiro, A. M. (1995). Incorporation of the cholera toxin receptor in phospholipid-covered polystyrene microspheres. Colloids and Surfaces B: Biointerfaces, 5, 1-2, (Sep 1995) 57-64, ISSN 0927-7765.

Singh, R. ; Tian, B. \& Kostarelos, K. (2008). Artificial envelopment of nonenveloped viruses: enhancing adenovirus tumor targeting in vivo. FASEB J., 22, 9, (Sep 2008) 3389-402, ISSN 0892-6638.

Sobral, C. N. C. ; Soto, M. A. \& Carmona-Ribeiro, A. M. (2008). Characterization of DODAB/DPPC vesicles. Chem Phys Lipids., 152, 1, (2008 Mar) 38-45, ISSN 00093084.

Soo, P. L. ; Dunne, M. ; Liu, J. \& Allen, C. (2009). Nano-sized advanced delivery systems as parenteral formulation strategies for hydrophobic anti-cancer drugs. In: Biotechnology: Pharmaceutical Aspects, Villiers, M. M. De ; Aramwit, P. ; Kwon, G. S. (Eds.), 349-383, Vol. 10 (Nanotechnology in Drug Delivery), Springer, ISBN 978-0387-77667-5, Heidelberg.

Suedholter, E. J. R.; Engberts, J. B. F. N.; Hoekstra, D. J. (1980). Vesicle formation by two novel synthetic amphiphiles carrying micropolarity reporter head groups. J. Am. Chem. Soc., 102, 7, (Mar 1980) 2467-69, ISSN0002-7863.

Talmon, Y.; Evans, D. F. ; Ninham, B. W. (1983). Spontaneous Vesicles Formed from Hydroxide Surfactants: Evidence from Electron Microscopy. Science., 221, 4615, (Sep 1983) 1047-48, ISSN 0036-8075.

Tamm, L. K. \& McConnell, H. M. (1985). Supported phospholipid bilayers. Biophys J., 47, 1, (Jan 1985) 105-13, ISSN(electronic) 1542-0086.

Tápias, G. N. ; Sicchierolli, S. M. ; Mamizuka, E. M. \& Carmona-Ribeiro, A. M. (1994). Interactions between Cationic Vesicles and Escherichia coli. Langmuir, 10, 10, (Oct 1994) 3461-65, ISSN 1053-0509.

Thevenot J, Troutier AL, Putaux JL, Delair T, Ladavière C. (2008). Effect of the Polymer Nature on the Structural Organization of Lipid/Polymer Particle Assemblies. J Phys Chem B., 112, 44, (Nov 2008) 13812-22, ISSN 1089-5647.

Traueble, H. \& Eibl, H. (1974). Electrostatic effects on lipid phase transitions: membrane structure and ionic environment. Proc Natl Acad Sci U S A., 71, 1, (Jan 1974) 214-9, ISSN 0027-8424.

Troutier, A.-L. ; Delair, T. ; Pichot, C. \& Ladavière, C. (2005). Physicochemical and Interfacial Investigation of Lipid/Polymer Particle Assemblies. Langmuir 21, 4, (Feb 2005) 1305-13, ISSN 1053-0509. 
Troutier, A-L. \& Ladavière, C. (2007). An overview of lipid membrane supported by colloidal particles. Adv. Colloid Interface Sci., 133, 1, (May 2007) 1-21, ISSN:0001-8686.

Tsuruta, L. R.; Lessa, M. M. \& Carmona-Ribeiro, A. M. (1995). Interactions between dioctadecyldimethylammonium chloride or bromide bilayers in water. Langmuir, 11, 8, (Aug 1995) 2938-43, ISSN 0743-7463.

Tsuruta, L. R. ; Lessa, M. M. \& Carmona-Ribeiro, A. M. (1995). Effect of particle size on colloid stability of bilayer-covered polystyrene microspheres. J. Colloid Interface Sci., 175, 2, (Nov 1995) 470-5, ISSN: 0021-9797.

Tsuruta, L. R. \& Carmona-Ribeiro, A. M. (1996). Counterion Effects on Colloid Stability of Cationic Vesicles and Bilayer-Covered Polystyrene Microspheres. J. Phys. Chem., 25, 100, 17, (Apr 1996) 7130-4, ISSN 0022-3654.

Tsuruta, L. R. ; Quintilio, W. ; Costa, M. H. B. \& Carmona-Ribeiro, A. M. (1997). Interactions between cationic liposomes and an antigenic protein: the physical chemistry of the immunoadjuvant action. J Lipid Res., 38, 10, (Oct 1997) 2003-11, ISSN 0022-2275.

Urban, M. W. \& Lestage, D. (2006). Colloidal particle morphology and film formation; the role of bio-active components on stimuli-responsive behavior. Polymer Rev., 46, 4, (Dec 2006) 445-66, ISSN 1558-3724.

Velinova, M. J. ; Staffhorst, R. W. ; Mulder, W. J. ; Dries, A. S. ; Jansen, B. A. ; de Kruijff, B. \& de Kroon, A. I. (2004). Preparation and stability of lipid-coated nanocapsules of cisplatin: anionic phospholipid specificity. Biochim. Biophys. Acta., 1663, 1-2, (May 2004) 135-42, ISSN 0006-3002.

Vidard, L. ; Kovacsovics-Bankowski, M. ; Kraeft, S. K. ; Chen, L. B. ; Benacerraf, B. \& Rock, K. L. (1996). Analysis of MHC class II presentation of particulate antigens of B lymphocytes. J. Immunol., 156, 8, (Apr 1996) 2809-18, ISSN 1526-34.

Vieira, D. B. \& Carmona-Ribeiro, A. M. (2001). Synthetic Bilayer Fragments for Solubilization of Amphotericin B. J. Colloid Interface Sci., 244, 2, (Dec 2001) 427-31, ISSN 0021-9797.

Vieira, D. B. ; Pacheco, L. F. \& Carmona-Ribeiro, A.M. (2006). Assembly of a model hydrophobic drug into cationic bilayer fragments. J. Colloid Interface Sci., 293, 1, (Jan 2006) 240-7, ISSN 0021-9797

Vieira, D. B. \& Carmona-Ribeiro, A. M. (2006). Cationic lipids and surfactants as antifungal agents: mode of action. J Antimicrob Chemother., 58, 4, (Aug 2006) 760-7, ISSN 03057453 .

Vieira, D. B. \& Carmona-Ribeiro, A.M. (2008) Cationic nanoparticles for delivery of amphotericin B: preparation, characterization and activity in vitro. Journal of Nanobiotechnology, 6, article 6, (May 2008) E-ISSN:1477-3155.

Xu, J. ; Stevens, M. J. ; Oleson, T. A. ; Last, J. A. \& Sahai, N. (2009). Role of Oxide Surface Chemistry and Phospholipid Phase on Adsorption and Self-Assembly: Isotherms and Atomic Force Microscopy. J. Phys. Chem. C, 113, 6, (Feb 2009) 2187-96, ISSN $1932-7447$.

Yang, J. ; Tamm, L. K. ; Tillack, T. W. \& Shao, Z. (1993). New approach for atomic force microscopy of membrane proteins. The imaging of cholera toxin. J. Mol. Biol., 229, 2, (Jan 1993) 286-90, ISSN 0022-2836

Zuzzi, S. ; Cametti, C. \& Onori, G. (2008). Polyion-Induced Aggregation of Lipidic-Coated Solid Polystyrene Spheres: The Many Facets of Complex Formation in Low-Density Colloidal Suspensions. Langmuir, 24, 12, (Jun 2008) 6044-49, ISSN 0743-7463. 


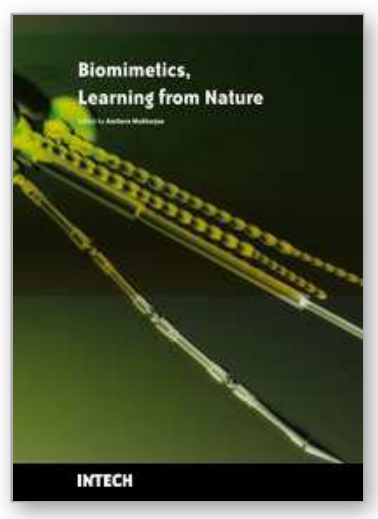

\section{Biomimetics Learning from Nature}

Edited by Amitava Mukherjee

ISBN 978-953-307-025-4

Hard cover, 534 pages

Publisher InTech

Published online 01, March, 2010

Published in print edition March, 2010

Nature's evolution has led to the introduction of highly efficient biological mechanisms. Imitating these mechanisms offers an enormous potential for the improvement of our day to day life. Ideally, by bio-inspiration we can get a better view of nature's capability while studying its models and adapting it for our benefit. This book takes us into the interesting world of biomimetics and describes various arenas where the technology is applied. The 25 chapters covered in this book disclose recent advances and new ideas in promoting the mechanism and applications of biomimetics.

\section{How to reference}

In order to correctly reference this scholarly work, feel free to copy and paste the following:

Ana Maria Carmona-Ribeiro (2010). Lipid-based Biomimetics in Drug and Vaccine Delivery, Biomimetics Learning from Nature, Amitava Mukherjee (Ed.), ISBN: 978-953-307-025-4, InTech, Available from: http://www.intechopen.com/books/biomimetics-learning-from-nature/lipid-based-biomimetics-in-drug-andvaccine-delivery

\section{INTECH}

open science | open minds

\section{InTech Europe}

University Campus STeP Ri

Slavka Krautzeka 83/A

51000 Rijeka, Croatia

Phone: +385 (51) 770447

Fax: +385 (51) 686166

www.intechopen.com

\section{InTech China}

Unit 405, Office Block, Hotel Equatorial Shanghai

No.65, Yan An Road (West), Shanghai, 200040, China

中国上海市延安西路65号上海国际贵都大饭店办公楼 405 单元

Phone: $+86-21-62489820$

Fax: +86-21-62489821 
(C) 2010 The Author(s). Licensee IntechOpen. This chapter is distributed under the terms of the Creative Commons Attribution-NonCommercialShareAlike-3.0 License, which permits use, distribution and reproduction for non-commercial purposes, provided the original is properly cited and derivative works building on this content are distributed under the same license. 